\title{
Manipularan Walter Benjamin. Una altra volta a les Tesis
}

\author{
Arnau Pons \\ 17, Instituto de Estudios Críticos \\ Cascada 180 \\ Colonia Jardines del Pedregal de San Ángel \\ Alvaro Obregón, CP 01900, Ciudad de México \\ obriulls@gmail.com \\ ORCID: 0000-0002-7767-245X
}

\section{Resum}

L'article fa un repàs crític de la recepció de les Tesis de Benjamin a Catalunya a partir de diversos articles de la premsa cultural, a més d'uns quants textos d'especialistes sobre l'obra benjaminiana, tot coincidint amb la publicació recent de tres traduccions al català de l'opuscle «Sobre el concepte d'història», amb motiu del vuitantè aniversari de la mort del filòsof a Portbou.

Paraules clau: Walter Benjamin; Tesis; manipulació; races; premsa; elits; transmissió cultural; progrés; messianisme; revolució; traducció; crítica; Heidegger; tècnica; Agamben; Pau de Tars

Abstract. They will manipulate Walter Benjamin. Another turn of the Screw on the Theses

The article makes a critical review of the reception of Benjamin's Theses in Catalonia based on several articles in the cultural press, as well as some texts by specialists on Benjamin's work, coinciding with the recent publication of three Catalan translations of the booklet «On the Concept of History», on the occasion of the 80th anniversary of the death of the philosopher in Port-Bou.

Keywords: Walter Benjamin; Theses; manipulation; races; press; elites; cultural transmission; progress; messianism; revolution; translation; critique; Heidegger; technique; Agamben; Paul of Tarsus

Amb la citació que diu que «ni tan sols els morts no estaran segurs davant l'enemic, si venç», extreta de la Tesi vi de l'opuscle pòstum Sobre el concepte d'història, de Walter Benjamin, el diari Le Monde (30 de juny de 2020) denunciava la instrumentalització que s'estava a punt de produir amb la figura del pensador jueu alemany tot just quan s'albirava el vuitantè aniversari de la seva mort. De cop i volta, unes paraules fosques i rotundes de Benjamin es podien aplicar a ell premonitòriament, per bé que el fet d'indagar el futur mai no havia estat cosa 
seva. Un visionari és, al cap i a la fi, algú que hi veu clar. Afirmar que «aquest enemic no ha parat de vèncer» (Benjamin 2019: 39) no té res d'oracular ni de profètic. És una constatació. El demostratiu («aquest enemic») l'identifica. Se sap prou bé quin és. I avui l'afer és recargolat: el nou batlle de Perpinyà, Louis Aliot, del partit ultradretà de Marine Le Pen, ha decidit de reprendre amb tota pompa, per al seu programa, el projecte del Centre d'Art Walter Benjamin —obert d'ençà del 2013 sota el mandat del batlle anterior, Jean-Marc Pujol, però que de fet ha romàs gairebé inactiu i sense rumb durant una bona partida d'anys. $\mathrm{El}$ «perill» de què parla Benjamin en aquesta Tesi vi està a punt de caure sobre ell i la seva obra per l'oportunisme d'un polític que cerca una manera de maquillar el partit. A dir veritat, però, la instrumentalització ja s'havia produït des del moment que Pujol creava un centre d'art servint-se de l'esquer de Benjamin per seduir l'electorat d'esquerra. Si ara, amb Aliot, la instrumentalització ha arribat al seu comble, és perquè la figura de Benjamin s'ha anat usant molt més per fora que per dins, fins a convertir-se en una atracció turística amb regust d'història $i$ amb una pàtina de transcendència que satisfà unes consciències massa avesades a una relació sovint ràpida i sempre enjogassada amb la cultura. No hi ha dubte que la travessia pels Pirineus i la mort a Portbou han anat agafant, amb el pas del temps, una dimensió crística innegable, perquè té tot d'elements que s'hi presten: el calvari de la ruta amb l'enigmàtica maleta, la decisió d'entregar-se a una mort inevitable i alliberadora, cosa que va permetre d'alliberar de retop el grup que l'acompanyava; una mort esdevinguda a la frontera, una sutura que cus la serralada pirinenca fins a la blavor del mar, amb tot el que significa simbòlicament la frontera com a tanca de separació, de pas controlat i alhora de frontissa arbitrària entre contrades; i, sobretot, la figura d'un màrtir jueu que projecta al món un sacrifici de reclam universal, víctima del mal radical que aleshores minava Europa. D'aquesta manera, Portbou s'ha convertit en un punt de pelegrinatge, recolliment i meditació. I diria que això no és pas el resultat de la teologia «petita i lletja» a què es refereix Benjamin a la Tesi I, sinó més aviat de la religió tal com ell l'analitzava (Löwy 2019: 11-34), amb els seus rituals i el seu culte savi al negoci — unes pràctiques culturals pròpies del capitalisme.

Aquí va ser La Vanguardia que amb el títol «El "affaire" Walter Benjamin» (6 d'agost de 2020) en va explicar el cas fil per randa, pocs dies després d'haver publicat una notícia sobre la reacció esverada de l'Acadèmia de les Arts de Berlín, dipositària de l'arxiu del pensador, davant l'operació d'Aliot. La diferència entre un article i l'altre és que Le Monde començava fent una referència també molt crítica a l' «escape town» que Francesc Ribera, àlies Titot, havia muntat a Portbou inspirant-se en l'atzucac en què es va trobar Benjamin una vegada al poble - una instrumentalització macabra que de seguida va provocar un cert enrenou i el fet que Ribera es disculpés per la utilització de la sort del filòsof en una activitat d'entreteniment. (Val a dir que el cas ja havia tingut un precedent lúdic amb l'Escape room del Teatre Goya, que tenia Auschwitz com a marc i el doctor Mengele com a terror.) El cert és que La Vanguardia ha informat només de l'afer escandalós de Perpinyà. Fins ara les seves pàgines han passat sota silenci la nova edició catalana de les Tesis de Benjamin a l'editorial Flâneur — Sobre 
el concepte d'història, el seu testament intel-lectual, com se n'ha dit-, un silenci que contrasta amb la importància que sembla que donen al personatge en el vuitantè aniversari de la mort. L'actitud de La Vanguardia s'explica perfectament des de Benjamin mateix, si tenim en compte les seves observacions sobre el relat dels vencedors o sobre el poder i la seva transmissió cultural. Tanmateix, aquest silenci és encara més cridaner pel fet que tenim al davant una edició genètica única: no només inclou totes les variants a la vista, sinó també les imatges dels manuscrits custodiats per Hannah Arendt, així com les de les versions franceses - o autotraduccions, o millor dit reformulacions- que Benjamin mateix en va fer, a més de les vacillacions i les ratlladures, cosa que palesa l'estat inconclús i esbossat d'aquests textos, sense que això els tregui el mèrit de ser llegits com un dels opuscles filosòfics i polítics més importants del segle xx, per la lucidesa política (una crítica a l'esquerra d'aleshores) i també per la vigència antifeixista i ecològica. Però a l'equip de ressenyes de La Vanguardia la feina de comentar Benjamin els deu venir grossa, perquè ni tan sols es veuen amb cor de fer-ho recolzant-se en l'Avís d'incendi, el cèlebre assaig de Michael Löwy, publicat l'any 2020 també a Flâneur, i això explica que en el vuitantè aniversari de la mort del filòsof acabin simplement parafrasejant Le Monde, amb la convenció de les recurrents fotografies hagiogràfiques.

I tanmateix Benjamin va ser, en vida, un «intellectual marginal, que es va negar a jugar el joc institucional, marxista radical però comunista sense credo, situat aferrissadament a fora», tal com n'ha dit Edwy Plenel en el seu pròleg a una reedició de la traducció que Léa Marcou va fer de les memòries de Lisa Fittko, Le chemin Walter Benjamin. ${ }^{1}$ Fins avui dia, però, i a mesura que la seva aura mediàtica creix a còpia d'anècdotes (basta llegir, a tall d'exemple, la nota morbosa i frívola sobre «Benjamin i Barcelona» de Jordi Llovet a l'Ara Llibres, del 30 d'octubre de 2020), fins avui dia, deia, han anat apareixent al voltant del seu nom — i de les seves icones emblemàtiques — tot de satèl-lits més o menys acadèmics, més o menys institucionals, que el reivindiquen i es valen del seu llegat, sovint per demanar diners — concretament, dos milions i mig d'euros, segons la crònica de Sebastià Bennàssar a VilaWeb (26 de setembre de 2020), i això vol dir que, com ha passat amb La Vanguardia arran del vuitantè aniversari de la mort, als de VilaWeb també els surt més a compte fomentar el mite i l'embalum monetari que no pas comentar les noves edicions que se'n fan en català. Una cul-

1. Aquest pròleg d'Edwy Plenel ha provocat un malestar profund a Samuel Sandler, germà de Léa Marcou, la traductora. Sandler creu que Plenel ha utilitzat aquest prefaci sobre Benjamin per llançar dures crítiques contra l'Estat d'Israel, sense venir-hi a tomb, perquè ni tan sols entra a discutir les polítiques de Hamàs o de Hizbollà, per exemple, o la posició del gran Mufti de Jerusalem durant el nazisme. Cal tenir en compte que els nets de Sandler (nebots-nets de Marcou) van ser assassinats a Tolosa per Mohamed Merah davant l'escola jueva a la qual anaven, i que Léa Marcou va emigrar a Israel, on va morir. Tots són enterrats a Israel. El llibre de Fitkko agafa una dimensió inesperada i llòbrega per als familiars de Marcou. L'ús polític de Benjamin per causes que ell no va arribar a tractar és sempre, inevitablement, un terreny relliscós. Vegeu la reacció de Sandler, disponible a la xarxa: <https://fr.timesofisrael.com/samuel-sandler-se-confiesur-lombre-qui-plane-sur-un-livre-traduit-par-sa-soeur/?utm_source=A+La+Une\&utm_ campaign=a-la-une-2020-10-22\&utm_medium $=$ email $>$. 
tura mostra les seves aspiracions i prioritats així. I ara torno a remarcar que la traducció de la Teoria del partisà, del jurista nazi Carl Schmitt, sí que va tenir el seu espai tant a La Vanguardia com a VilaWeb quan va sortir - i en el cas de VilaWeb va ser d'una manera totalment positiva. Pel que fa al poeta Paul Celan, la sort a Catalunya encara li ha estat més llòbrega. El 23 de novembre del 2020 se'n celebrava el centenari, amb tot d'actes, col-loquis, recitals i publicacions arreu d'Europa i d'Amèrica, i és ben xocant constatar que un poeta com ell, que ha deixat una empremta fonda en la poesia del segle $\mathrm{xx}$, no hagi tingut una trista nota a la premsa ni als espais culturals o podcasts de les ràdios d'aquí, si tenim en compte que la llista de poetes catalans que hi ha mantingut alguna mena de relació intertextual és llarguíssima. El fet que la revista Reduccions hagi tret, en el número 115 , dedicat a la poesia croata contemporània, uns pocs textos sobre la seva obra i la seva recepció, arran del centenari, es deu a la pròpia iniciativa i perquè el comitè s'hi va avenir tot d'una.

Però encara és més xocant que en l'efemèride de VilaWeb, Sebastià Bennàssar esmenti al final, de passada, i com si fos una novetat, la reedició del volum Art i literatura, una tria de textos de Benjamin, amb les Tesis incloses, ara amb el títol restituït d'Art i literatura de masses (Edicions Reremús / Fundació Angelus Novus, 2020), tal com informa en el pròleg la responsable de la reedició, Pilar Parcerisas, i que tanmateix Bennàssar no citi (en el sentit que Benjamin dona a les Tesis) el nom de l'artífex de tot plegat:

La fundació és molt activa. Aquest cap de setmana s'hi farà l'escola d'estiu, com cada any, en memòria del filòsof. Serà [...] una ocasió per a presentar la traducció al català del llibre Art i literatura de masses. (Bennàssar 2020)

Amb aquesta informació, difícilment podem capir que es tracta de la reedició, trenta-sis anys després, de la pionera traducció del volum de textos diversos de Benjamin a cura d'Antoni Pous, que va sortir pòstumament el desembre de 1984, i que ara surt amb un afegit significatiu en el títol amb què va aparèixer llavors. Tantes omissions, així com el fet que l'article recolzi en bona part en les necessitats pecuniàries de la Fundació Angelus Novus, fan palès que els textos de Benjamin són del tot secundaris, a pesar de la remembrança que ell mateix invoca sovint per a una justícia històrica de les generacions esborrades. De fet, el títol de l'article no pot ser més explícit: «Walter Benjamin espera el centre on li retin memòria vuitanta anys després de la seva mort a Portbou», com si la supervivència de Benjamin depengués dels rituals de memòria i de la salut econòmica d'aquest centre, en lloc de l'actualització dels seus textos per mitjà de la traducció i de la lectura contrastades —unes activitats que són molt més modestes en les despeses i sovint més anònimes a causa d'una premsa al servei exclusiu d'unes elits. Potser el periodista transmetia simplement allò de què l'havien informat des de la Fundació. I si és així: quin sentit pot tenir, per a la Fundació, aquest escamoteig, tant del nom de Benjamin com a autor de la publicació anunciada, com del seu introductor a Catalunya, davant la imperiosa necessitat dels diners que sostindran la seva seu de Portbou? Era perquè no volien entrar en competència, potser, 
amb la nova traducció de Flâneur, a càrrec de Marc Jiménez Buzzi, o perquè la seva reedició de Pous havia de passar una mica desapercebuda? És tan negligible que apareguin tres traduccions al català de les Tesis, ço és, la de Gustau Muñoz al número 58 de L'Espill la primavera del 2018, la de Flâneur el 2019 a càrrec de Marc Jiménez Buzzi per als textos en alemany i a càrrec meu pel que fa a les versions franceses de Benjamin mateix, i la reedició del recull pioner d'Antoni Pous el 2020, o de debò compten més els avatars i vicissituds dels centres i les fundacions benjaminians, arran del seu centenari? És gaire habitual que, en l'efemèride d'un autor, no es remarqui ni comenti enlloc que hi ha disponibles tres traduccions catalanes recents d'un opuscle tan actual com són les Tesis, i que, en canvi, els reclams i les fretures dels gestors que es dediquen a Benjamin ocupin les planes de la premsa diversa, des de La Vanguardia fins a VilaWeb?

Que prevalgui el «Benjamin icona», buidat de contingut i esquer de subvencions, per damunt dels seus textos polítics, retraduïts i reeditats, pot explicar-se per un funcionament lent, o, com és de suposar, que no arriba a abastar-ho tot, però el cert és que quan un llibre de Schmitt tan connotat com La teoria del partisà preval per damunt d'un de Benjamin, en un mitjà marcat políticament, és perquè Schmitt els deu semblar útil i Benjamin (ja) no. Tal com diu la Tesi III: res del que s'hagi esdevingut no estarà perdut per a la història. Tampoc les ressenyes i les no-ressenyes de les edicions en català. És obvi que la millor manera de desactivar un pensador és aquesta: treure'l a rotlle sense comentar el que escriu - perquè, com diu Franz Hessel a la seva ressenya de Carrer de sentit únic (Einbahnstrasse; a Das Tagebuch, del 3 març de 1928): «Les seves paraules expressen una invitació permanent a participar, a prendre part de la reflexió». I això és extrapolable a la resta del que va escriure.

Si Benjamin s'ha vinculat d'una manera tan profunda amb Baudelaire, és perquè «Baudelaire ha definit, per primera vegada, aquesta relació que el poeta, tot havent perdut l'aura, manté amb la poesia» (Wismann 2013: 155). No hi ha res més lluny del pensament benjaminià que un Benjamin aurat. Res no treu més força als seus escrits que una certa promoció i celebració mediàtiques o institucionals - l'arrabassen del seu espai exterior en el qual ell es volia, per tal de ferne una figura tova i salvadora, gestionada i vehiculada per les elits. Ens ha de sobtar gaire, doncs, que l'extrema dreta de Perpinyà vulgui entrar en aquest mateix joc quan Benjamin ja ha esdevingut, en els àmbits de l'esquerra i centreesquerra, «l'objecte d'un culte anàleg al dels sants de les religions "ordinàries"» (Löwy 2019: 15)? O és que no hi ha hagut lectures que, segurament per interès — com Derrida (Capella 1993: 369, n. 4), que necessitava justificar el seu heideggerisme fent de Benjamin un pensador tant o més inquietant que Heidegger amb relació a la 'solució final'-, lectures que han associat, per exemple, «el veritable estat d'excepció» de què parla a la Tesi viII amb «l'estat d'excepció» de Carl Schmitt, quan en realitat, si els llegim bé a tots dos, ens adonem que no tenen res a veure, perquè en Benjamin l'estat d'excepció és allò que trenca l'Estat autoritari, mentre que en Schmitt és allò que el consolida (Löwy 2020: 119-124; Rosàs 2016: 55-64)? O és que la manipulació i la instrumentalització de Benjamin és un fenomen nou? 
Just en el moment del seixantè aniversari de la seva mort —o sigui, fa vint anys-, Jordi Llovet ja es queixava de la manipulació de Benjamin en una entrevista que li va fer Lluís Bonada a la revista El Temps. El catedràtic de teoria de la literatura i de literatura comparada de la UB hi lloava el treball que havia fet ell mateix amb Benjamin els anys 1990-1991, amb motiu del cinquantè aniversari de la mort, a través de la Societat d'Estudis Literaris i de 1'Institut d'Humanitats, sota el seu lideratge, i que havia donat lloc al volum Walter Benjamin i l'esperit de la modernitat (1993), l'aplec de totes les ponències. El seu argument contra la «Conferència Internacional Walter Benjamin: Crossing borders / Travessar fronteres», que havia estat plantejada des de fora de Catalunya i que tenia lloc a la UB i a Portbou (del 25 al 27 de setembre del 2000), era que «no [feia] justícia intel-lectual al filòsof i en manipula[va] la figura». El títol de l'entrevista ho deixava clar: «Manipularan Walter Benjamin». Tota la seva crítica recolzava en la qüestió política: «El manipularan políticament per fer ecumenisme», reblava. D'entrada, però, quins eren els actors d'aquest col-loqui internacional que tant irritava Llovet? No n'ha quedat gaire rastre, a dir veritat. Si hem de fer cas de l'única ressenya que se'n pot trobar, de la mà d'Esther Leslie (disponible a la xarxa), en tindrem una impressió boirosa i ben diferent de la que em va fer a mi. Val a dir, a més, que Leslie s'ha dedicat a Benjamin i n'és part interessada, per bé que s'agraeix que es desmarqui de tot el que no la convenç — com ara la intervenció d'Adam Michnik, per poc centrada. Pel que fa a mi, era la primera vegada que em trobava davant d'algú que havia conegut Benjamin, com Stéphane Hessel, que anys després faria d'altaveu a Barcelona arran del 15-M amb el moviment dels «indignats». També hi havia intel-lectuals i professors que l'havien treballat, com Irving Wohlfarth, deixeble d'Adorno, amb un llibre que havia sortit recentment a Mèxic el 1999; Stéphane Mosès, amb L'Ange de l'histoire, del 1992; Bernd Witte, que n'havia fet l'única biografia accessible aleshores en català; o Mauro Ponzi, de Roma, que encara ara continua publicant sobre Benjamin, a diferència de Jordi Llovet que no té cap llibre sobre el pensador, tan sols textos esparsos que no s'han traduït ni han circulat fora d'aquí. Però l'autèntica descoberta, per mi, va ser Idith Zertal, amb una intervenció molt crítica sobre Gershom Scholem, a causa de la seva no-gestió del llegat de Benjamin a Israel. En realitat, cap d'aquests ponents no va fer una aportació que anés en la línia de l'ecumenisme que denunciava Llovet. En comptes d'això, l'exposició intel-ligent d'Idith Zertal em va fer seguir la petja d'aquesta historiadora, fins que vaig publicar-ne La nació i la mort a la col-lecció Traus, de Lleonard Muntaner. I tanmateix, el professor Llovet, a qui també havien convidat, es va negar a participar-hi, bo i brandant l'argument que manipularien Benjamin «en favor de la idea de transfronterisme, d'ecumenisme». Perquè, segons ell, la «temptació d'utilitzar-lo políticament és molt forta». I tenia raó. Avui Perpinyà en torna a ser l'exemple. Però cal dir-ho tot: la temptació d'utilitzar-lo políticament és molt forta, com també ho és la d'utilitzar-lo per fer-se un lloc institucional o per consolidar un espai fet a mida, a fi d'afermar-se així en la gestió d'una cultura controlada de sempre per les elits, fins i tot en allò que és suposadament trencador o marginal. Que potser tenia por, Jordi Llovet, de no saber què dir i de posar en dubte, allà, el seu prestigi 
benjaminià? Por de confrontar-se amb veritables experts? $\mathrm{O}$ és que el mèrit d'anunciar, a l'entrevista d'El Temps, una tria de textos de Benjamin per al 2001 amb el títol d'Assaigs de literatura comparada — una cosa que pot fer qualsevol que l'hagi llegit de cap a cap_, sense ni tan sols prologar-los (el pròleg és d'Ignacio Echevarría), ni tampoc traduir-los, és gaire gran? El cert és que no hi va haver cap sessió que mirés de fer «ecumenisme» amb el pensament benjaminià; a tot estirar, es va plantejar de vegades la interdisciplinarietat de la seva obra, atesa la influència que ha tingut i té en el món de l'art i de la reflexió política i social. De fet, la primera edició de Benjamin al català en forma de llibre — almenys, de què tinc constància- és un aplec del 1983 que du per títol L'obra d'art a l'època de la seva reproductibilitat tècnica, en què hi ha, a més del text homònim, la «Petita història de la fotografia» $\mathrm{i}$ «Eduard Fuchs, el colleccionista i historiador», en traducció de Jaume Creus i amb un pròleg de J. F. Yvars. I cosa curiosa: l'assaig cabdal sobre l'obra d'art es va tornar a publicar poc temps després, el desembre del 1984, en traducció d'Antoni Pous i amb un títol lleugerament diferent: «L'obra d'art en l'època de la seva reproduïbilitat tècnica», dins el recull Art $i$ literatura, en què hi havia altres textos de Benjamin, a més de les Tesis —unes traduccions que, segons explica Manuel Carbonell a la «Nota de l'editor» (una edició força descurada, tot s'ha de dir), s'havien fet —o potser iniciat— l'any 1968, però que van trigar molt a sortir a la llum per problemes amb els drets i per dilacions i entrebancs de tota mena. ${ }^{2}$ Tal com informa també Carbonell, de fet Segimon Serrallonga ja n'havia aconseguit de publicar «La tasca del traductor» al número 4 de la revista Reduccions d'abril del 1978. En acarar-les, les traduccions de Creus i de Pous són força diferents; en general, Pous pot ser desordenat sintàcticament, imprecís en la tria lèxica i matusser o capritxós estilísticament. Les seves traduccions de Celan i de Benjamin tenen una factura semblant i donen compte d'un esperit inquiet i pioner, a l'aguait de les lluors del seu temps, i per al qual la traducció de dos autors difícils i compromesos havia de servir per a l'enfortiment i la recuperació de la llengua i la cultura catalanes. Com n'ha dit Pilar Parcerisas:

Emprèn una traducció agosarada sobre temes rellevants de la modernitat, un concepte força allunyat de la grisor que vivia el país sota el franquisme i, a més, ho fa amb l'intent de dotar la llengua catalana d'un cos de pensament universal contemporani del qual sempre ha estat mancada. El seu mèrit és ser-ne el pioner, afrontar les dificultats d'una tasca ingent, no sense defectes. Malgrat les imperfeccions, ha estat un llibre de referència per als que ens vàrem iniciar en l'obra de Walter Benjamin a l'inici dels anys vuitanta. (Parcerisas 2020: 7)

És com si el fosc destí jueu europeu, a partir del seu anorreament gairebé total, prengués una significació concreta per al destí de la cultura catalana, sempre precari, i per això Pous s'esmerça per donar veu en català a Celan i Benjamin,

2. Les vicissituds es poden seguir a la tesi de Ramon Farrés, disponible a la xarxa: <https://www. tdx.cat/handle/10803/5254\#page=1>. 
quan tot just començaven a traduir-se a altres llengües. En el seu text d'introducció, els rampells de lucidesa no hi manquen: «Heidegger qüestiona el sentit de l'ésser i acaba cercant les rels de l'ésser en les rels dels mots»; o també: «Heidegger, entre els filòsofs, quan arriba el moment, posa també com a bon herbolari la seva arreplega de rels al servei del nazisme» (Pous 1984: 13-15), tot i que alhora en valora el pas important que representa quant a la «fretura de l'ésser», que no és altra cosa que una voluntat d'autenticitat en l'existència per mitjà del poble (que s'amuniona al voltant del Führer), la llengua (amb la poesia i la filosofia sublimades) i la pàtria (hereva d'una Grècia instrumentalitzada).

Només quan es faci inevitable, Llovet esmenta la feina pionera d'Antoni Pous, qualificant-la d' «excel-lent traducció» (l'elogi grinyola perquè és obvi que presenta problemes), sense entrar mai a comentar-la (Llovet 2008: 368). ${ }^{3}$ De manera semblant, en lloc d'acceptar el debat sobre Benjamin amb els seus collegues estrangers, decidirà que li surt més a compte assegurar que ells el presentaran «com un conciliador de religions, de races» i que això «no [n'és] el cas». Un cop diagnosticat el mal, ja no hi voldrà perdre més temps. Més enllà que aquestes declaracions seves puguin tenir un deix reaccionari — amb la referència a les 'races', quan hauria d'haver dit 'cultures' - i que solen ser pròpies d'un discurs provincià ressentit i sobretot acomplexat; més enllà també que Llovet sembla que s'interessa exclusivament per allò que ell fa i organitza; i més enllà del seu tarannà mofeta (amb frases de la mena: «Que a partir d'ara la gent es pensi que Benjamin era una espècie de metge sense fronteres»), el cas és que a l'entrevista també es pot permetre de posar en dubte l'expertesa de Jorge Semprún, convidat al col-loqui, pel que fa a l'obra benjaminiana, però curiosament ell sí que va poder convidar el professor Jaume Casals a fer una conferència «Sobre les tesis de filosofia de la història de Walter Benjamin» en el marc del cinquantè aniversari de la mort, inclosa finalment en el volum que havia curat, Walter Benjamin $i$ l'esperit de la modernitat (1993). Perquè, si ens la llegim, de seguida ens adonem que deu haver-hi pocs fracassos tan estrepitosos, del món acadèmic estant, en el comentari d'aquests textos. Amb una escriptura expeditiva i no gaire llustrosa (no hi manquen els castellanismes, com l'ús de «tessitura» en lloc d'estat d'ànim, o la «por a ser contradit» en lloc de la por de ser contradit), el text de Jaume Casals no diu absolutament res d'allò que se suposa que hauria d'il-luminar. L'autor no només fa gala del seu menyspreu per l'opuscle pòstum de Benjamin, sinó que es vanta també de la incomoditat que li provoca. De bon començ admet que Llovet l'ha obligat a escriure sobre les Tesis amb la seva «disciplina de ferro» i reconeix «la [seva] incompetència en el tema benjaminià» (Casals 1993: 329), una incompetència que li ve d'una «certa militància» sostinguda («anti-benjaminiana, antiadorniana, anti-horkheimeriana [...] anti-habermasiana»). Valenta manera de treballar el llegat de Benjamin i, sobretot, valenta estafa. El professor Llovet sap que a Catalunya ningú no el contradirà si fa escarni públic d'un collloqui interna-

3. Ho fa en el mateix volum de Carrers de frontera (2008), en què Josep Maria Lluró apunta una influència de Benjamin en el treball de l'historiador Josep Fontana i també en l'obra de l'artista Francesc Abad, a més de parlar de Pous. 
cional dedicat a Benjamin (com poques vegades se n'han fet), perquè també sap que pot presentar-se'n com l'expert i erigir-se en el gestor intellectual de l'obra, de manera que pot jutjar qui és apte per parlar-ne i qui no, i, per tant, coordinar sota la seva batuta tot un grup de persones que segons ell sabran fer ponències sobre el pensador heterodox amb molta més pertinència i volada que Stéphane Mosès, Bernd Witte, Idith Zertal, Irving Wohlfarth o Mauro Ponzi. Ara bé, un detall que no podem perdre pas de vista és que l'any 2013, quan va sortir el monogràfic sobre Benjamin del Cahier de l'Herne, hi vaig tornar a trobar Stéphane Hessel, Stéphane Mosès, Bernd Witte i Irving Wolhfarth, però no hi havia —ai las! - cap text del professor Llovet, i això que a Patricia Lavelle, la curadora, no se li pot retreure que no cerqués, desesperadament, un acadèmic ibèric per al dossier. Fins i tot es va posar en contacte amb Vicente Valero, de qui havia llegit Experiencia y pobreza. Walter Benjamin en Ibiza (1932-1933), un llibre que l'autor eivissenc hauria volgut publicar simultàniament en català l'any 2001 i per això es va basquejar per aconseguir un ajut que en cobrís la traducció i l'edició (les institucions d'Eivissa hi tenien tota la bona voluntat), però l'editor de Barcelona (Península-i-Empúries) va considerar que era millor que els catalans no poguessin triar la llengua de l'assaig; potser creia que editar-lo en català era debades (com tirar els diners), a pesar de l'atracció que exerceix Benjamin tant per amor de Portbou com d'Eivissa (no es pot dir que el llibre de Valero no sigui d'allò més llegívol, ni es pot negar tampoc que acosta els eivissencs i de retop els catalans a la cultura europea). Però és bo de saber —si volem entendre per què hi ha una davallada tan dràstica de les matriculacions a filologia catalana- que aquest ha estat, justament, durant massa temps, el càlcul tàctic —o l'insondable càlcul tàctic_ - de les elits catalanes en la seva política lingüística, pel que fa a les traduccions i a les edicions en català. I ha passat exactament el mateix amb el llibre que Joan Miró va fer amb Georges Raillard, El color dels meus somnis, que estava traduït a diverses llengües, tret del català, com si no calgués que els catalans llegissin aquest llibre extraordinari en la llengua pròpia de Miró, fins que vaig editar-lo l'any 2008 en traducció de Joaquim Sala-Sanahuja a Traus. ${ }^{4}$ Deu ser que, segons les nostres elits, l'esperit català s'ha de destinar essencialment a la poesia (la de Carner en primer lloc). I suposo que només és l'assaig en català el que acaba convertit en pasta de paper, però no pas els llibres de poesia ni tampoc les novelles — si no, el seu càlcul tàctic no s'entén. Tal vegada tot això — vull dir aquesta fretura conscient i mantinguda d'un pensament en català, vinculada a un menyspreu cap al que ve de fora- podria explicar que, fins avui dia, mai no hagin convidat conseqüentment el professor Llovet a un col-loqui internacional sobre Benjamin. Amb aquestes pràctiques de conreu, és difícil que una producció assagística i hermenèutica pugui resultar interessant a l'estranger. El cas és que

4. De fet, en castellà encara ara es reedita, però censurat, com en la primera edició que se'n va fer el 1978, ço és, amb les parts sobre política catalana tretes del llibre, perquè aquest Miró justament no els agrada. I això encara fa grinyolar més l'entrevista de Reyes Mate, el gran especialista en Benjamin a Espanya, quan diu que en la construcció nacional catalana hi ha una expressió del franquisme, però no s'adona —o fa com qui no s'adona— que la història l'escriuen ells. 
una cultura que no aposti veritablement pel pensament crític ni per l'assaig no tindrà mai «herois» ${ }^{5}$ disposats a lluitar a l'arena internacional.

Dit això, no puc sinó fer una reverència davant dels textos de Marisa Siguán, de Raffaele Pinto, d'Alberto Cardín o de Nora Catelli, per exemple, inclosos en el volum de 1993 curat pel professor Llovet. S'haurien de reeditar perquè no han perdut una unça de vigència. I tanmateix, arribats en aquest punt, potser ens hauríem de preguntar quin devia ser el veritable motiu del rebuig cap a aquell colloqui internacional. Era perquè al darrere hi bategava la idea de crear una Casa Walter Benjamin a Portbou, un projecte que ja disposava d'un esbós arquitectònic de Norman Forster, amb el suport d'un grup d'intel-lectuals de fora —alguns dels ponents - que temptejaven o cercaven la complicitat catalana per poder dur a terme aquella proposta ambiciosa? I no deu ser que el professor Llovet veia que això feia perillar seriosament la seva hegemonia? Són preguntes retòriques llançades al buit i que arrosseguen certament una mica d'història amagada. Si ara són útils, és perquè fan palès que els judicis sobre les lectures de Benjamin solen tenir al darrere un interès personal. Es posa en dubte la legitimitat d'un discurs perquè del que es tracta, en definitiva, és de continuar servant el poder del discurs - a fi d'utilitzar-lo per llegir-sense-llegir. No és aquesta la millor manera de neutralitzar un pensador? L'expressió burleta que Llovet utilitza a l'entrevista per referir-se al Benjamin del collloqui, un «metge sense fronteres», com també la de «conciliador de religions, de races», que potser no posa en evidència el petit Aliot que, com un nan lleig i amagat, el professor Llovet porta a dins?

Benjamin pot ser utilitzat políticament de manera prou diversa. L'especialista espanyol per excel-lència de Walter de Benjamin, el professor Reyes Mate, ha arribat a la conclusió, per exemple, que les urnes que més de dos milions de persones vam defensar l'1 d'octubre a Catalunya són una expressió del franquisme, perquè el dret a votar un dilema polític implica la violència que hauria estat el fet d'obligar una part de la societat catalana a entomar un resultat que, segons el professor, l'exclouria, ja que, segons ell, el nacionalisme català és, en bloc, d'arrel franquista i excloent. Val la pena llegir el tros de l'entrevista en què ho explica:

Pregunta: Es que en España la guerra sí la ganó el fascismo.

Respuesta: Es la gran diferencia. En Europa el fascismo perdió, aquí no. La República fue vencida dos veces. Primero, por el fascismo. Pero después la derrotaron los aliados al dejarla de lado y legitimar el franquismo. Esa doble derrota ha complicado el deber de memoria.

P: Estos días, en las crónicas internacionales sobre el conflicto catalán, reaparece el franquismo como si fuera un elemento más de la política española. ¿Es justo?

R: Creo que es una manipulación del pasado. Si hay una expresión del franquismo en el caso catalán, no está tanto e[n] la brutalidad de la policía reprimiendo el simulacro de referéndum, sino en la forma de entender la construcción nacional catalana. Tirarse a una piscina como era esa apuesta por una república catalana teniendo en cuenta que la mitad estaba en contra, que no se daban las

5. Manllevo el mot a Pagès Jordà, expert en assaig català. 
condiciones... Ese gesto expresa una forma de ser hispana: construir excluyendo. Ahí se representa el esquema español más castizo. En esto los nacionalistas catalanes son los más españoles de todos. Esto lo tiene el nacionalismo español, el castellano, el vasco y también el catalán. Todos son profundamente españoles. No tiene sentido enfrentar el nacionalismo español al catalán. Los dos son resultado de la misma forma histórica a la que se refería Américo Castro. (Munárriz 2017)

Aquest és l'argumentari d'un especialista benjaminià espanyol davant d'un fenomen colllectiu d'empoderament pel dret a decidir, «malauradament efímer», com va ser aquell referèndum pacífic per on corrien aires que ja han circulat en algunes de les revolucions ofegades pel feixisme (Löwy 2020: 211). No ens ha d'estranyar, doncs, que els policies diguessin en el judici-farsa que va venir després, que els vam obligar a pegar-nos. La brutalitat, avisa el benjaminià Reyes Mate, està més en el vot que en la porra. Amb tot, un ús polític —-fecund, a parer meu - totalment oposat al pensament ultranacionalista de Reyes Mate (que sempre defensarà l'statu quo), el trobem en l'assaig de Silvana Rabinovich sobre un altre nacionalisme, intitulat «El vuelo del Angelus Novus por los campos de refugiados de Tinduf. Cavilaciones benjaminianas» (Rabinovich 2020). Aquest deu ser sense cap mena de dubte el Benjamin ecumenista que tant desplau a Jordi Llovet: un metge sense fronteres, tal com va alertar en El Temps.

Ara bé, dir que «[l'] originalitat del mètode de Benjamin en proposar-se estudiar el París del segle XIX és [...] anàloga a la de Plató en reflexionar sobre la ciutat-Estat grega del segle de Pèricles» (Llovet 1993: 283) és una pirueta que no treu cap enlloc, perquè fa topar dos projectes filosòfics i polítics radicalment diferents —i tant la lectura benjaminiana de Baudelaire, amb les seves al-legories que desfiguren les illusions urbanes (Berdet 2014: 281), com les reflexions desplegades a L'obra d'art en l'època de la seva reproductibilitat tècnica, com també les seves anàlisis sobre el surrealisme, ho demostren a bastament. Plató busca la funcionalitat de la ciutat, severament si cal. Benjamin mira per una distribució justa, mitjançant la revolució si cal. Ni tan sols la concepció benjaminiana del llenguatge és (neo)platònica, sinó, com argumenta molt bé Raffaele Pinto, materialista i iconoclasta, en el marc d'una superació utòpica de la cultura moderna i del seu antropocentrisme (Pinto 1993: 60-64). Tampoc no crec que «la idea benjaminiana de la història» (Llovet escriu «la idea de la història benjaminiana») tingui res a veure amb «la lúcida passivitat d'un Bartleby, el personatge de Melville que "s'estima més no fer-ho", no fer res de productiu segons les lleis de producció del capitalisme» (Llovet 1993: 288), perquè el raonament no s'aguanta. Cal distingir, d'entrada, entre la idea o la visió de la història (una anàlisi) i el posicionament davant del capitalisme (una resposta o reacció). Llovet confon totes dues coses. De fet, el seu text presenta sovint imprecisions i esllavissades interpretatives; també una mescladissa de conceptes no gaire ben entesos i, per tant, mal travats. Comentar un autor recorrent a la lliure associació, és a dir, tot partint de les lectures i ocurrències que un té el cap, pot ser fecund sempre que no se'n desvirtuï l'obra, que és el que ell fa.

En realitat, si hi ha un acte en què la passivitat s'imposa per Benjamin -0 sigui, el fet de «no fer res de productiu segons les lleis de producció del capitalis- 
me»—, és justament la vaga general com a ressort revolucionari mitjançant el qual es pot expressar la violència divina —una violència que té el poder de destruir, al seu torn, la violència mítica i, de retop, el marc de l'Estat autoritari (Butler 2014: 76s i 88s). Com apunta Michael Löwy en el seu assaig sobre les Tesis: «Allò que Benjamin retreu a la socialdemocràcia d'inspiració neokantiana és, sobretot, el seu immobilisme» (Löwy 2020: 198). No hi ha dubte que Llovet es projecta ell mateix en la seva interpretació, perquè el que li interessa al cap i a la fi és de mantenir l'statu quo (igual que a Reyes Mate). Si hi ha res que caracteritzi la història que Benjamin analitza, és que els vencedors construeixen el seu relat tot esborrant el dels vençuts — cosa que Llovet no diu mai quan parla de la idea benjaminiana de la història-, i també que el progrés, lloat fins i tot pel marxisme, és imparable, bàrbar, infernal, opressor (Löwy I988: 138s), i d'aquí ve la necessitat d'activar «els frens d'emergència» (Löwy 2020: 135). I tanmateix, tot fent de Benjamin un personatge passiu, melangiós, allunyat de l'heroi romàntic [?] — com l'Hipèrion de Hölderlin, amb el qual sí que s'aparellaria en certa manera Baudelaire [?] — Llovet precisa que:

a Benjamin ja tot és excèntric, desplaçat, inclassificable, més pròxim a la comèdia de la vida quotidiana que a les dimensions transcendentals de la tragèdia, i sobretot, impotent, és a dir, estrany a tota esfera de poder. Aquesta és la posició de Benjamin respecte al microcosmos de la ciutat, com ho és, per extensió, respecte de la història contemporània. (Llovet 1993: 288; la cursiva és meva)

Queda clar, doncs, que «la posició de Benjamin [...] respecte de la història contemporània» equival, segons Llovet, a «la idea de la història benjaminiana». En el seu lèxic, «posició» $\mathrm{i}$ «idea» són sinònims, és evident. $\mathrm{O}$ sigui que la mirada de Benjamin sobre la història contemporània coincidiria amb la seva presa de posició envers aquesta història. És una manera curiosa d'interpretar-lo — per no dir que és «excèntrica, desplaçada, inclassificable». Amb tot, en comentar la Tesi VII, Löwy ha mostrat prou bé que Benjamin separa la seva visió pessimista de la història, de l'acció que cal prendre, segons ell, per trencar-la, perquè es tracta «d'organitzar el pessimisme» (Löwy 2020: 106s). I si es donés el cas que, per «contemporània», Llovet es refereix exclusivament a la història del capitalisme, aleshores ni la visió ni la posició de Benjamin serien «impotents», com fa palès el seu text «El capitalisme com a religió» (Löwy 2019: 11-34), o també la seva proposta política de vaga general sostinguda.

Tot i això, a Löwy no li passa per alt que «un dels grans mèrits de Baudelaire als ulls de Benjamin és precisament el reconeixement desesperat d'aquesta impotència», referint-se al fet que «la rememoració com a tal és impotent per transformar el món», ço és, la rememoració d'un passat edènic, sense classes —i que, per tant, la resposta benjaminiana a aquesta impaciència i ràbia baudelairianes cal trobar-la a les Tesis de 1940 amb «la revolució proletària que pot i ha de dur a terme la interrupció messiànica del curs del món» (Löwy 1988: 154s).

En realitat, tot el paràgraf de Llovet que he citat més amunt —i que és important retenir perquè mostra millor o pitjor el bessó del seu pensament sobre Benja- 
min — té un redactat confús a causa d'una errada en la preposició, que fa ballar tot el plantejament («a», quan hauria de ser «en»), però també perquè hi falten nexes o connectors textuals. D'acord amb la formulació, hem d'entendre que «a Benjamin ja tot [li] és [és a dir, li resulta] excèntric, desplaçat, inclassificable [...], i sobretot, impotent», però tot i això la frase no lliga bé amb la conclusió: «és a dir, [tot li resulta] estrany a tota esfera de poder». Sembla que vol dir que, a Benjamin, ja tot li resulta impotent davant la història (i que no hi ha res a fer), amb la qual cosa, finalment, fins i tot Benjamin mateix sembla que pren posició a favor de la impotència i s'allunya així de tota esfera de poder. La impotència jugaria, doncs, a totes bandes, en ell i fora d'ell —com un fet immutable i com una determinació.

Que Benjamin no volgués «jugar el joc institucional», com apunta Plenel, que és el joc que sí que juga Llovet tota l'estona (fins i tot quan diu adeu a la universitat), el fa estrany, potser, «a tota esfera de poder»? El fa «impotent»? No és més potent justament perquè decideix no jugar aquest joc que tot ho domestica? És impotent el seu text «Per una crítica de la violència», o pot ser summament potent si és portat fins a les últimes conseqüències? No és la idea messiànica de Benjamin - o l'origen místic de la revolució — una manera de conjurar tota impotència? La revolució a la qual aspira per combatre l'Anticrist, seria impotent? Per què hi aspira, doncs? No hi ha dubte que Löwy llegeix en Benjamin tot allò que Llovet evita de llegir:

Per què aquest poder messiànic és feble (schwache)? Com ha suggerit Giorgio Agamben, hi podríem veure una referència a un paràgraf de la segona carta de Pau als Corintis (2 Cor. 12,9-10): per al Messies, «quan soc feble és quan soc realment fort» —en la traducció de Luter: meine Kraft ist in den Schwachen mächtig [Agamben 2006: 136-137]. Però l'expressió també té — probablement- una significació política actual: és la conclusió melangiosa a què Benjamin arriba a partir dels fracassos passats i presents del combat emancipador. La redempció és lluny d'estar assegurada, només té una ínfima possibilitat d'èxit i cal saber aprofitar-la. (Löwy 2020: 74s)

Per Benjamin, l'esfera de l'autoritat no pot ser sinó colllectiva, i, per tant, no té sentit parlar d'impotència: tot depèn del moment que la Revolució francesa o el Regne messiànic tinguin l'oportunitat de fer irrompre la seva plena actualitat. És un avís i és també una injunció. Però Llovet no es pot estar de barrejar conceptes per tal d'amaçar una sola idea:

La tesi setena de la sèrie sobre filosofia de la història [...] resumeix perfectament aquesta impotència i aquesta inviabilitat ètica pròpia de la darrera visió benjaminiana del progrés: «No hi ha cap document de cultura que no ho sigui al mateix temps de la barbàrie». (Llovet 1993: 288; la cursiva és meva)

Una vegada més, «posició» $\mathrm{i}$ «visió» són per ell equivalents, bescanviables. La visió que Benjamin tindria del progrés és d'impotència a conseqüència del fet que la cultura porta sempre en ella la barbàrie, i això fa que la cultura mateixa 
caigui en una inviabilitat ètica. És realment així? Perquè del que es tracta, al final d'aquesta Tesi viI, és de raspallar la història a contrapèl, a fi de regirar i alçar el pèl massa llustrós de la història, amb la intenció de fer aflorar tot allò que, pel fet d'estar amagat, no s'ha vist ni llegit. Que un document de cultura ho sigui alhora de barbàrie assenyala el treball anònim dels qui, oprimits, explotats o espoliats, hi han intervingut, però també remet a la injustícia de classes en la transmissió del llegat cultural (i això inclou l'educació). La Tesi vir no té res a veure amb la impotència perquè justament hi ha la possibilitat de fer una recerca històrica diferent. I és en aquest gest de raspallar a contrapèl que rau la viabilitat ètica del qui es dedica al materialisme històric. A més, com assenyala Löwy a Avís d'incendi, la cultura i la barbàrie no són dues etapes diferents de l'evolució històrica, sinó que «Benjamin les presenta dialècticament com una unitat contradictòria (Löwy 2020: 107)». La lluita entre l'una i l'altra és constant, cosa que també ha demostrat prou bé, després de Benjamin, la poesia —o la contra-poesia- de Paul Celan, de manera que encara hi ha una forma de viabilitat ètica possible. No va interessar-se, Benjamin, per l'obra d'Anna Seghers, Leskov o Kafka justament per això? (cf. Löwy 2020: 78).

A més, sostenir que «la idea de la història benjaminiana» té «a veure [...] en [sic] la brutal concentració d'intel-ligència de Paul Valéry» (Llovet 1993: 288), fent una mena d'identificació o de fusió entre l'un i l'altre — simplement perquè Benjamin hauria escrit sobre Valéry «que no havia aconseguit de "passar el cancell que va de l'obra d'art a la comunitat humana», i que per tant «l'intel-lecte continua essent privat, i aquest és el misteri malencònic de Monsieur Teste"»—, és no adonar-se del distanciament crític que Benjamin mateix agafa en aquest text sobre l'escriptor francès, de qui fa sorgir justament les mancances polítiques i socials. N'hi ha prou de llegir el comentari que Antonio de Murcia, de la Universitat d'Alacant, fa d'aquest mateix text de Benjamin sobre Valéry, per adonar-nos de la inviabilitat ètica de Llovet a l'hora de comentar l'obra benjaminiana. Val la pena llegir-ne el paràgraf sencer:

Reformulando los elogios de su anterior texto para el sexagésimo aniversario del poeta, el crítico [Benjamin] apunta aquí a la impotencia evidente de un pensamiento que se queda en el umbral de lo que anuncia, incapaz de desprenderse del ídolo que denuncia. El escritor [Valéry] habría entendido efectivamente el carácter del espíritu como producción; siguiendo la idea de progreso del «período heroico de la burguesía europea» había colocado al sujeto ante el umbral de sí mismo y al poeta ante el reto de una poiesis literaria que, antes que creación, era cálculo, construcción, planificación, método, e invitaba atravesar el umbral de lo privado. Pero, lejos de atravesarlo, dice Benjamin, «Valéry no logró trasladar esta idea de planificación desde el ámbito propio de la obra de arte al ámbito que es propio de la comunidad humana». Su contraejemplo sería el amigo André Gide, quien traspasó ese umbral hasta el punto de que, integrando su producción en su vida moral y no sólo en su vida intelectual, se adhirió al partido comunista. También lo fueron los poetas surrealistas, que partiendo de las mismas aporías de la subjetividad poética que diseccionó Valéry, proclamaron que la producción poética era necesariamente una tarea colectiva. Benjamin vio en ellos el genuino lugar social 
y político de los poetas y citó, como un inesperado mentor, al viejo Lautréamont para explicarle a Valéry que «la poesía ha de ser hecha por todos, no por uno». No nos consta que Valéry le respondiera; ni siquiera que leyera este ensayo. Seguramente lo habría juzgado en función de unas exigencias políticas ocasionales e incluso destructivas; pero habría tenido una dificultad insuperable para vencer el principal argumento de su crítico: su incapacidad para proyectar la idea de producción del ámbito del intelecto al ámbito de la comunidad humana. Esta sería un síntoma y también un factor de esa asimetría e incongruencia entre los productos del espíritu, de esa distancia política del hombre europeo consigo mismo, en la que el propio poeta advirtió el mayor peligro para la supervivencia de su espíritu. «El intelecto — concluirá Benjamin — aún vive en lo privado, y éste es el secreto melancólico que guarda el señor Teste». (De Murcia 2018: 19)

Allà on Llovet veu la impotència en Benjamin, Benjamin la veu en Valéry. Les intencions del professor no poden ser més clares. I en tenim un altre exemple llampant amb una frase com ara aquesta:

Portar l'actitud del flâneur fins a aquestes «últimes conseqüències intel-lectuals» va significar per a Benjamin, en darrer terme, assolir una concepció del món enormement penetrant, però que s'obliga immediatament a si mateixa a submergir-se en el «silenci polític». (Llovet 1993: 290)

Això és justament el que l'intèrpret hauria volgut, però aquest no és, ni de tros, el llegat de Benjamin. No se'l pot llegir en virtut d'aquest pretès silenci —inexistent, d'altra banda-, si no és forçant-lo fins a desvirtuar-lo completament. D'una manera obstinada, Llovet haurà fet tot el que haurà pogut per situar Benjamin en el «lloc tranquil i estàtic de tot misticisme» (ibídem). Ara bé, en aquest mateix volum collectiu, Raffaele Pinto explica molt bé que:

la posició de Benjamin apunta cap a una potenciació del concepte de llengua, que ell entén com a flux existencial, un entrar en contacte i transformar-se, un comunicar-se de les coses les unes amb les altres. [...] I, de tota manera, si el tret més característic del misticisme és el culte a l'inefable, Benjamin és contundent en afirmar que «com més profund, és a dir, com més existent i real és l'esperit, més és expressable i expressat». (Pinto 1993: 60s)

Hi ha molts passatges com aquest que fan aparèixer les llacunes que té i manté Llovet pel que fa als textos de Benjamin. Ni tan sols es va plantejar aleshores, en el moment de l'edició del volum col-lectiu del 1993, la viabilitat ètica del comentari mateix. És per això que cal destapar aquesta manipulació, que no és només cultural, sinó sobretot política, i que demostra, una vegada més, a la llum de les Tesis, que tot document de cultura és alhora un document de barbàrie. Perquè la barbàrie rau també en aquella interpretació que neutralitza el contingut revolucionari i crític dels textos (Cassirer 1947: 327-352).

Més endavant, per acabar d'estintolar la seva teoria del silenci, citarà el fragment d'una carta que Benjamin va adreçar a l'amic suís Max Rychner quan treballava en l'obra de Kafka i en què al-ludeix al Talmud —com si el Talmud fos, 
segons Llovet, la prova fefaent de la mística jueva (qualsevol que s'hagi acostat seriosament al Talmud sabrà que més aviat és el contrari):

Faig tot el que puc per dirigir el meu pensament cap a temes en els quals la veritat aparegui el més concentrada possible [...] Mai no he estat capaç d'investigar o de pensar de cap altra manera que no fos amb esperit teològic, és a dir, d'acord amb la doctrina del Talmud dels quaranta-nou nivells de significat de la Torà. (Llovet 1993: 290)

És ben simptomàtic que no donés la continuació immediata d'aquesta carta, carregada d'ironia, perquè la citació prendria un altre tomb. De fet, José María Valverde sí que en cita el passatge sencer a la «Introducció» del volum colllectiu curat per Llovet mateix (Valverde 1993: 34-35), perquè hi volia mostrar l'afecció de Benjamin pel comunisme davant les crítiques que rebia de la part de Scholem per aquest mateix motiu. Dono el fragment de carta de bell nou:

[...] m'esforço tant com puc per conduir la direcció del meu pensament cap a aquells temes en què la veritat aparegui com més concentrada millor. [...] Mai no he pogut investigar ni pensar de cap altra manera que no sigui, si se'm permet de dir-ho, amb sentit teològic —és a dir, segons l'ensenyança talmúdica que diu que cada versicle de la Torà té quaranta-nou nivells de sentit. Ara: d'acord amb la meva experiència, el tòpic comunista més gastat té més jerarquies de sentit que no pas la profunditat de pensament de la burgesia actual, que només en posseeix un de sol: l'apologètic. [[...] Ich bestrebt bin, die Richtung meines Denkens auf diejenigen Gegenstande zu lenken, in denen jeweils die Wahrheit am dichtesten vorkommt. [...] Ich habe nie anders forschen und denken können als in einem, wenn ich so sagen darf, theologischen Sinn - nämlich in Gemäßheit der talmudischen Lehre von den neunundvierzig Sinnstufen jeder Thorastelle. Nun: Hierarchien des Sinns hat meiner Erfahrung nach die abgegriffenste kommunistische Platitüde mehr als der heutige bürgerliche Tiefsinn, der immer nur den einen der Apologetik besitzt.]

Per tant, queda ben palesa la manipulació del professor Llovet. Dit això, també s'ha de dir que gairebé mai no s'ha comentat que Benjamin es va empescar aquesta idea dels «quaranta-nou nivells de sentit d'un versicle de la Torà», perquè el Talmud no diu tal cosa. I sovint aquesta declaració seva s'agafa i se cita com si tingués una base certa. És possible que, arran d'alguna lectura, li rodés pel cap l'ensenyament dels quatre nivells de significació que es pressuposen per a una plena interpretació de la Torà, segons la lliçó del Pardés — que vol dir 'Paradís' segons els cabalistes, tot i que és un terme d'origen persa per designar un «verger», i que es desfà com un acrònim en els nivells de significació: p’xat (literal), rémez (al-lusiu), draix (sol-licitat) i sod (esotèric). Potser aleshores Benjamin va barrejar això, sense voler, amb el relat sobre els quaranta-nou nivells d'impuresa espiritual que van davallar els hebreus durant l'esclavatge a Egipte, de manera que havien de remuntar-los tots, un cop lliures, dia rere dia, per poder rebre la Torà al Sinaí — un relat que dona significació al còmput dels quarantanou dies que hi ha entre la Pasqua i la Festa de les set setmanes (o sigui 49 dies). Un dels llibres cabdals de la Càbala, el Zohar, es refereix a aquests quaranta-nou 
nivells d'impuresa (Emor 97 i H'adaix Itró 39), i també ho fa el Ialkut Ximoni (Xemot 234 i 238), que és un aplec medieval jueu alemany d'explicacions aggàdiques de la Bíblia hebrea. Esmento aquestes dues obres com a meres suposicions que podrien explicar el lapsus en el nombre quaranta-nou pel que fa als nivells de sentit de cada versicle de la Torà. Fins ara no he trobat ningú que mirés de donar la referència exacta d'aquesta declaració benjaminiana tan i tan citada.

No hi ha dubte que, a mesura que anava descobrint alguns textos de la tradició jueva, hi podia trobar una font d'inspiració constant, però més a la manera del flâneur, que no pas del que s'hi dedica sistemàticament, com va ser el cas de Scholem. Ara bé, en ell la mística no mena al «silenci polític»—com bé exposa aquesta carta si no la llegim amputada-, sinó a l'acció alliberadora o redemptora, mai exempta d'una forta dimensió política revolucionària.

Jordi Llovet posa el punt final al seu text amb la conclusió del fracàs de Benjamin. Ço és: davant de l'enigma urbà, «la teoria calla» (Llovet 1993: 290). La gran ciutat es torna «una nova Llei» i, segons que sembla, tan inassolible com la de Kafka, que no esmenta aquí, tot i que l'argumentació és massa idèntica a la que se sol utilitzar per a l'escriptor de Praga. I és que en definitiva un jueu val per l'altre. Al capdavall, diuen si fa no fa el mateix. L'ètnia i la Llei fan un tàndem que funciona. Amb el seu flâneur, Benjamin només hauria pogut arreplegar citacions i documents esparsos, incapaç a l'hora d'elaborar un discurs coherent que aconseguís d'ajuntar totes les peces per tal de descloure'n la veritat oculta:

És com si un discurs sobre el progrés s'hagués ofert voluntàriament al sacrifici per no malmetre la veritat que tanquen, per ells mateixos, els documents esparsos de la cultura urbana. (Llovet 1993: 290)

El Benjamin que projecta no pot ser més inoperant. N'hi ha prou de mirar-se la lectura que Löwy desplega a Avís d'incendi per adonar-nos que el seu discurs sobre el progrés implica tota una altra cosa. Abans, Jacob Taubes, molt crític amb l'estetització del messianisme que faria Adorno a Minima Moralia, ja havia donat una dimensió nihilista i destructiva —és a dir, anarquista (Löwy 2018) — al messianisme de Benjamin, arran del comentari del «Fragment teològico-polític», que molts intèrprets llegeixen conjuntament amb les Tesis (Taubes 2005: 182-186). I val a dir — ja que aquí es tracta de retraducció- que l'edició catalana dels cursos de Jacob Taubes aplegats sota el títol de Teologia política de Pau (2005) ha estat feta a partir de la traducció francesa publicada el 1999, en comptes de l'edició alemanya, revisada el 2003. Per afegitó, aquesta traducció d'una traducció ha estat adaptada —se'ns diu— pel traductor, Jordi Galí i Herrera, força crític amb Taubes des del seu catolicisme militant, de manera que el lector pot recórrer a la castellana del 2007, si vol tenir al davant una traducció feta directament de l'alemany — cosa que no impedeix que en la traducció castellana no pugui haver-hi badades monumentals, com quan transforma l'escriptora «Glückel de Hameln» en «el flautista de Hamelin» (Taubes 2007: 23).

També la conferència del professor Casals sobre les Tesis palesa, com ja he dit, una gran incomprensió —en el seu cas volguda i proclamada—, a més d'un 
desconeixement orgullós del judaisme, que de vegades s'apropa a un antisemitisme ambiental de baixa intensitat i que sol ser la marca d'identitat de la cultura grecocristiana europea, com quan diu:

Cal saber, doncs, quan Benjamin parla en clau de pensament post-il.lustrat alemany genuí i quan adopta la tessitura [sic] que l'aproxima al poble escollit pel Déu de l'Antic Testament. (Casals 1993: 329)

Hi ha cap indici, en Benjamin, que ens faci pensar que aquí —o en alguna altra banda— reivindiqui filosòficament el concepte de «poble escollit», o és que aquesta etiqueta tan gastada no destapa un prejudici del professor? Què significa «la masticació reflexiva del pa sense llevat», o sigui el pa alís de la Pasqua jueva (ibídem)? Vol dir potser que tota referència al judaisme implica sequedat i amargor? A què treu cap, doncs, aquesta disjuntiva plantejada d'una manera tan rude? Quin deu ser, per Casals, el «pensament post-illlustrat alemany genuí»? Té cap vinculació, potser, amb el pensament antiil-lustrat alemany? Es refereix al romanticisme alemany, com ara el d'un Schiller, atret també per la mística? O es deu referir a Hamann, el Mag del Nord, lector de la Càbala? És que la genuïnitat del pensament alemany post-il-lustrat exclou el jueu quan agafa les fonts jueves?

Es fa difícil entrar a debatre la conferència de Jaume Casals: no se la pot agafar per enlloc. Es pot precisar, per exemple, que «la concepció jueva del temps» no es fonamenta en l'espera, tal com ell sosté, perquè el temps en hebreu pot presentar tres substantius: z'man, 'et i 'olam (aquest últim pot ser espacial o temporal). De fet, tota espera es pot resignificar i defineix més aviat una actitud. Els evangelistes messiànics també esperen, però esperen altrament i també quelcom d'altre. Però aquesta discussió no aporta res sobre allò de què es tracta aquí, o sigui les Tesis; només serveix per qüestionar els tòpics sobre la concepció jueva del temps.

Potser el que se'n pot extreure, després de llegir pàgines crispades que no diuen gairebé res —només rondinen o es queixen-, és que les Tesis serien una mera «aproximació poètica a la història» (Casals 1993: 333), aproximació que «té alguna cosa de malson i de follia», i a la qual es fa difícil, per tant, de donar un valor transmissible, i menys encara de dir-ne alguna cosa concreta, pel fet que, segons el professor, es tracta d'un «text endimoniat i, d'ençà que vaig posar-me a llegir-lo, repetidament maleït». Però segurament no s'adona que tota l'estona no fa sinó compondre frases tenses que abandonen qualsevol mena d'argumentació. Estava realment preparat per llegir aquest opuscle? La crucifixió-sacrifici de Benjamin amb què acaba la conferència fa pensar que l'encàrrec potser l'ha acabat crucificant a ell. I mostra sense embuts que la por que tenen alguns acadèmics catalans de debatre amb experts vinguts de fora és ben justificada. Basta comparar la part que Löwy dedica a Benjamin en el seu llibre de 1988, Rédemption et utopie, o la que Stéphane Mosès li dedica en el seu llibre de 1992, L'Ange de l'histoire, amb els textos de Llovet i de Casals, publicats el 1993, per fer-nos una idea de l'abisme que els separa.

Amb tot, a fi de matisar l'opinió de Jaume Casals, s'ha de dir que Benjamin s'inscriu també en una tradició alemanya ben genuïna, amb una forta empremta 
de la mística i de la Càbala, representada per figures com ara Jakob Böhme, Johann Georg Hamann, Franz von Baader i Franz Joseph Molitor (Löwy 1988: 125), que pertanyen a un corrent que ha estat qualificat d'irracionalista o de l'anti-Il-lustració. També hi ha, en Benjamin, el pòsit de la lectura de Humboldt, pel seu concepte del llenguatge. A més, cal tenir en compte que al llarg del segle XIX les edicions de textos cabalistes hebreus van conèixer, a Alemanya, una embranzida considerable, de manera que també Scholem se'n va poder servir. Se sap que tant ell com Benjamin van treure profit dels quatre volums del filòsof i cabalista cristià Franz Joseph Molitor Philosophie der Geschichte oder über die Tradition (1824-1853). Per afegitó, Scholem assegura en una carta que la seva concepció de la filologia, o de la crítica filològica, s'articula al voltant de la mística, tal com passa en Schiller (Launay 2010: 86s i 95). Què vull dir amb tot això? Doncs que la dicotomia que planteja Casals — amb «el poble elegit» i «l'alemany genuí»— no té cap pertinència, a part que es fa hereva d'un pensament racialitzador que ja sabem on acaba. A dir veritat, en el Benjamin que se suposa més jueu, hi trobarem també conceptes pròpiament cristians i aliens al judaisme, com és la noció del «pecat original» en el seu assaig sobre el llenguatge (Benjamin 1984: 117) o de l'Anticrist de les Tesis (Benjamin 2019: 39). La hibridació judeoalemanya no sols es palesa en els autors jueus com ara Walter Benjamin, Joseph Roth, Hannah Arendt o Margarete Susman; també és visible en autors alemanys genuïns, com en diria Casals, citats més amunt.

L'aplec de ponències de 1993 a cura de Jordi Llovet té encara una altra intervenció que intenta fer llum sobre les Tesis. És la de Joan Ramon Capella, «El temps messiànic en l'últim Benjamin», una lectura que recolza excessivament en la paràfrasi del text que comenta, però que almenys n'aporta una traducció, si no de totes les Tesis, almenys sí de les que considera més significatives. Amb tot, el problema fonamental que planteja aquesta ponència és l'ús que fa del mite i la manera com l'integra en la matriu benjaminiana. Segons Capella, el «Paradís» de la Tesi Ix és «el lloc mític de la cultura», de manera que el «"progrés" és la força cultural mítica que impedeix obrar a l'innocent» (Capella 1993: 377). L'innocent seria l'Àngel, una criatura que té alguna cosa «en el seu imaginari collectiu» (Jung?) que la du a paralitzar el moviment emancipador: «és a dir, una força procedent d'un lloc mític impedeix obrar a la criatura innocent» (ibídem). Segons l'intèrpret, Benjamin «impregna de sentit "messiànic" profund la cultura emancipadora». Per tant, tot s'articularia entre «el lloc mític de la cultura» (el Paradís), «una força procedent» del Paradís (la tempesta) que impedeix a la criatura innocent (l'Àngel) d'obrar i, com a alternativa, la cultura emancipadora que Benjamin amara de messianisme (probablement, un messianisme antimític).

Aquesta lectura podria ser interessant — per la tensió entre cultura mítica i cultura crítica o antimítica- si no fos que parteix del concepte mític i cristià de messies. La perplexitat sobrevé quan Capella remet, de sobte, a El sagrat i el profà, de Mircea Eliade, i a la figura de Jesús de Nazaret com a model de la concepció jueva del temps. Perquè si cal, com diu ell, que «ens situem a l'interior de la cultura de qui històricament es va proclamar Messies» $\mathrm{i}$ «mirem de veure com és el temps pel messies mateix» (ibídem), per tal d'entendre la cosa messiànica 
de Benjamin, aleshores ens hem de preguntar on ha anat a raure Benjamin finalment, perquè tot això tira grapades de terra al damunt del que ell mateix ha escrit sobre la història. Té un concepte de temps, el messies, si ja ha vingut sota la forma de Jesús? És Jesús, com a figura històrica, que ens pot ajudar a entendre un concepte clau del judaisme, com ara la noció jueva del temps? No va ser això, d'alguna manera, una part del moll de l'os de la Disputa de Barcelona, amb Mossé ben $\mathrm{Na}$ 'hman de Girona i Pau Cristià com a actors principals? No s'entén gaire bé de quina manera el messianisme de Benjamin, si ve d'una concepció mítica cristiana, pot amarar la cultura emancipadora, perquè Jesús se situa al lloc mític de la cultura europea, ço és, el Paradís, segons Capella. El fet que s'hagués proclamat messies, o fos vist com a tal per una colla de jueus messiànics del seu temps, no impedeix que durant la història jueva no n'hagin aparegut d'altres, amb una certa significació històrica. I no podem deixar de banda que rabí Akiva, figura cabdal del judaisme, proclamés messies Ximon bar Kokhba —un nom que, escrit a la manera alemanya, Bar Kochba, no podia passar desapercebut a un jueu alemany com Benjamin, si tenim en compte que el 1910 es va crear a Hamburg, amb aquest nom, un grup esportiu jueu sionista que va donar lloc a altres grups homònims arreu d'Alemanya, d'Europa i de Palestina. El fet és que tant el rabí Akiva com el seu messies guerrer Bar Kokhba van ser martiritzats i executats pels romans — com Jesús_- mentre Judea era arrasada. Encara que Benjamin no fos atret pel sionisme, no podem deduir que la seva idea històrica de messies fos exclusivament la de Jesús, ni tampoc que la concepció del temps a l'època de Jesús sigui la que defineix paradigmàticament la concepció jueva del temps fins al segle Xx, que és el segle de Benjamin. És impossible que no hi hagués d'altres figures en el seu imaginari, pel fet que el judaisme ha estat, des de sempre, una cultura generadora de messies, com ara — a part de Jesús - Bar Kokhba mateix, l'aragonès Abraham Abulafia, Xabbetai Tsvi o Jacob Frank, tots ells fracassats com a tals. Val a dir que en el Talmud Jesús el messies és anomenat Bar Naflé, en arameu, que vol dir literalment «Fill dels avortaments», ço és, un messies potencialment fallit, pel fet que pot implicar sempre una possibilitat truncada, com cada vegada que hi ha hagut una oportunitat revolucionària que ha estat frustrada o perduda. De fet, Jesús no comportarà mai un acompliment messiànic per al judaisme, pel fet que el cristianisme s'acabarà convertint en una font inestroncable de matances, de persecucions i d'opressions per als jueus al llarg de la història. Creure que «aquest rabí» pot aportar una «lògica» útil (Capella 1993: 378) per entendre la «concepció lineal del temps» — projectada per l'espera— implica no veure que aquest mateix rabí sorgeix en el si d'una cultura messiànica que l'ha depassat del tot amb l'existència jueva diaspòrica, que és la de Benjamin. De fet, el judaisme es va haver de reformular de dalt a baix arran de la destrucció del segon Temple de Jerusalem, amb la dispersió d'una cultura que, d'ençà d'aleshores, va haver de repensar-se en — i des de-l'exili, de manera que el concepte de temps esdevé un altre. Per tant, Jesús és un de tants màrtirs del judaisme i un de tants messies que sorgeixen del seu si. No es pot ignorar, doncs, que hagi esdevingut el motiu principal pel qual molts de jueus hauran de patir en carn pròpia la seva mateixa Passió. A més a més, el calendari canvia amb el seu naixe- 
ment (l'1 de gener és la data de la seva circumcisió) i inaugura una nova etapa històrica, no exempta d'horror i de barbàrie. Aleshores, si el calendari, a diferència del rellotge, és un monument d'una consciència de la història, tal com planteja la Tesi xv, aquest calendari haurà de ser trencat de nou mitjançant una oportunitat revolucionària, definitivament messiànica, ara sí.

En comentar l'expressió «raspallar la història a contrapèl», Löwy rescata justament aquesta imatge emblemàtica que dona compte dels botins de guerra, arran de la destrucció del Temple de Jerusalem:

[...] l'antic model, present en la ment de tots els jueus, és l'Arc de Titus de Roma, que representa el seguici triomfal dels vencedors romans contra l'alçament dels hebreus, carregant els tresors robats al Temple de Jerusalem. (Löwy 2020: 105)

Les violències contra el poble jueu durant i després de l'adveniment de Jesús fan que el seu messianisme no es pugui desvincular de la inauguració d'una nova etapa històrica de vencedors i vençuts, en la qual ell acabarà situat —malgré lui- del costat dels opressors, o sigui, dels qui escriuen la història.

Si dic tot això és perquè, en el moment en què Joan Ramon Capella elabora el seu text, els cursos de Jacob Taubes sobre Pau de Tars, del 1987, encara no s'han traduït ni al català, ni a l'espanyol, ni a l'italià ni al francès. I Alain Badiou encara no ha fet el seu llibre sobre l'universalisme de Pau. Potser això explica que Capella confongui la missió de Jesús de Nazaret amb l'estratègia universalista de Pau (vegeu, si més no, Mateu 15 : 24). Hauria estat més pertinent, potser, o més fecund, que en comptes de partir d'aquell que, segons ell, seria l'únic messies històric que ha donat el poble jueu —i sobre el qual projecta una visió genèricahagués partit del messianisme paulí, com féu Agamben a Il tempo che resta (2000), per a qui Pau és el teòleg que, com un nan lleig, s'amaga dins del tauler de les Tesis benjaminianes.

La idea de Jacob Taubes és que tant Pau com Benjamin han fet una experiència bèl-lica que els marca i que en determina el messianisme. Per la seva banda, Agamben se serveix de Taubes com d'una prova que corrobora les seves troballes intertextuals paulines. Ara bé, el que se li pot replicar, a Agamben, és que els pocs termes de Pau que Benjamin cita sense cometes, via Luter, i de manera espaiada (Agamben 2006: 136), en realitat canvien de significació una vegada integrats a les Tesis —deixant de banda que el terme Erlösung, 'redempció' (ibídem: 140), no és en veritat una cita del Pau de Luter, sinó del Rosenzweig de L'estrella de la redempció (Der Stern der Erlösung, 1921), una de les lectures teològiques que més empremta van deixar en Benjamin. S'entén, doncs, que Löwy no s'estigui de matisar les troballes d'Agamben: el messianisme de Benjamin no és, de cap de les maneres, el messianisme crístic de Pau (Löwy 2020: 202, n. 201), cosa que ja havia remarcat Taubes anteriorment (Taubes 2005: 185s). També és Löwy que marca la distància que hi ha entre la teologia de l'alliberament de l'Amèrica Llatina, cristiana, i el messianisme revolucionari de Benjamin (Löwy 2020: 63s): és obvi que la teologia de l'alliberament busca una desconstrucció de l'Església per tal de retornar-la als seus objectius primordials, i sempre 
amb la idea que el patiment redimeix — de conformitat amb el patiment i la mort del messies.

El cert, però, és que les poques cites de Pau a les Tesis no impliquen una adhesió. Basta llegir el que Benjamin diu de la cita en el seu text sobre Karl Kraus per adonar-nos que cal separar-nos de les epístoles paulines si volem entendre com actuen aquests mots en el seu context nou:

En la citació salvadora i punidora la llengua es mostra com la mater de la justícia. Crida el mot pel seu nom, l'arrenca del context destructivament, però justament en fer-ho el crida altre cop al seu origen. Apareix en l'entramat del nou text, no pas desbaratat[:] sonor, encertat. (Benjamin 2001: 95)

Agamben mateix n'és conscient i per això escriu:

No sorprende, pues, que tales citas deban ser discretas y que de vez en cuando sepan cumplir de incógnito su labor. Esta tarea no es tanto de conservación cuanto de demolición: «La cita», se lee en el ensayo sobre Kraus, «llama a la palabra por su nombre, la arranca del contexto al que destruye»; la cita «salva y castiga» al mismo tiempo [II, 363]. En el ensayo «¿Qué es el teatro épico?» escribe Benjamin: «Citar un texto significa interrumpir el contexto al que pertenece». (Agamben 2006: 136)

Agamben ens té avesats a agafar cites d'una manera ben explícita —o sigui, entre cometes - i a anar saltant d'un text a un altre amb la intenció - se suposa- de seguir l'argumentació de l'autor citat. Tanmateix, molt sovint és per neutralitzar allò que l'autor diu i imposar una idea que ja ens tenia preparada. En aquest cas, la idea que defensa és que Pau és el nan petit i lleig que s'amaga dintre de les Tesis de Benjamin, des d'on mou els fils per tal de fer guanyar la partida a aquests textos. El messianisme no serà qualsevol: serà el de Pau, l'apòstol fundador del cristianisme. Però no s'adona de la contradicció en què cau quan diu que la cita en Benjamin — que és poc visible—destrueix el context d'on ve, amb la finalitat de salvar-la en un nou context que l'orienta cap al seu origen, a fi que pugui exercir la seva veritable labor. És a dir que Benjamin rescata de Pau allò que en Pau mateix ja va deixar de funcionar a causa d'un messianisme que no va resultar ser tal. El mot és retornat a la seva força originària, i per això cal destruir el text del qual prové. Es castiga Pau i se'n salven uns mots significatius. Tampoc no podem de perdre de vista que Luter va estudiar a fons l'hebreu i que va buscar l'assessorament de rabins; per tant, portava aquest bagatge quan va traduir del grec.

Ara bé, el primer que caldria plantejar, amb vista a una traducció catalana, és de quina manera aquestes remissions poden fer-se visibles o detectables, a fi d'evidenciar una relació intertextual amb les epístoles de Pau —una relació que, tanmateix, no serà mai la que s'estableix entre l'alemany de Benjamin i el de Luter. Que jo sàpiga, cap de les traduccions catalanes s'han proposat de fer palès aquest vincle, per bé que no sé fins a quin punt hauria estat possible (per exemple, el «typos» de Rom 5:14, traduït per «tipus» a la Bíblia de Montserrat i per 
«prefigurava» a la Bíblia interconfessional, difícilment pot donar la «imatge» que apareix en Luter i en Benjamin, i alhora fer explícita la cita).

I tanmateix: què permet d'assegurar que el messianisme de Benjamin no té res a veure amb el de Pau, tot i citar-lo puntualment a partir de Luter? Diria que n'hi ha prou d'analitzar el tipus de substitució que Pau du a terme en el si del judaisme i que afecta la naturalesa de la rememoració (Lévy 2020: 273-298), la qual cosa té com a consequiència que el primer dels deu manaments — sobre l'expressió de la divinitat - no coincideixi entre jueus i cristians, perquè per als jueus el tetragrama IHVH s'associa essencialment a l'alliberament d'Egipte (Segré 2014: 25). Així és: Pau canvia el deure de recordar l'alliberament d'Egipte — per tant, la idea d'una divinitat que mena a l'abolició de tota forma d'opressió, i amb la llibertat total com a finalitat de la creació- pel deure de recordar la mort del messies Jesús, simbolitzada en l'eucaristia, com a absolució del pecat d'Adam i de tota la humanitat. El de Pau és un messianisme de l'alliberament espiritual per la mort del messies, sempre recordada, i que eximeix alhora del jou dels preceptes de la Torà de Moisès, en un alliberament de la carn. Agamben no té en compte aquesta operació determinant de Pau, com si el seu messianisme no s'hagués particularitzat en una reformulació, perquè amb ell es passa d'un règim de santificació de la vida, mitjançant els preceptes i les obres (mitsvot), a un règim de sacralització de la mort, amb el patiment com a fonament de l'existència, com postula Antonio Negri en parlar de Job, fent una barreja de Marx i de Heidegger, no exempta d'una forta dosi de cristianisme. En realitat, aquesta potència del messies mort ja no té res de jueu. Hi ha un amor per la vida que s'ha perdut amb Pau i que s'ha convertit en un amor per la mort, tal com mostra la iconografia de les esglésies. No debades Franz Rosenzweig acaba L'estrella de la redempció amb una expressió significativa: INS LEBEN — cap a la vida. En el judaisme, també en el judaisme sui generis de Benjamin, el messies només pot ser vivífer. Res no fa pensar que en ell la idea de messies comporti en darrer terme la rememoració de la Passió, com en Pau. I això fa, doncs, que la intertextualitat descoberta per Agamben impliqui un gir corrector, de la part de Benjamin. Perquè és l'alliberament d'Egipte, com a esdeveniment inaugural de l'acció divina sobre un collectiu oprimit (format per hebreus i per egipcis dissidents del règim, val a dirho), allò que fa que el judaisme tingui una naturalesa essencialment revolucionària -i per tant es pugui posar al servei del materialisme.

La ponència de Joan Ramon Capella agafa un tomb diferent quan tracta la qüestió de la tècnica, perquè de seguida remarca la diferència entre Benjamin $\mathrm{i}$ Heidegger —és a dir, amb relació a la coneguda hostilitat heideggeriana cap a la tècnica-, sense deixar de comentar la crítica que Benjamin adreça a la sobreabundància o a l'excés tècnics «per a les necessitats de la vida», així com el fet que «el domini del món - i de la tècnica- és en mans opressores» (Capella 1993: 382 s). I és que les Tesis només es poden llegir des d'un allunyament total del pensament heideggerià, no només per la mena de crítica a la tècnica $i$ al progrés —o pel Messies vencedor de l'Anticrist nazi-, sinó també per la manera de concebre el passat i també la història. Al principi del seu llibre, Löwy qüestiona l'associació que va fer Hannah Arendt quan va afirmar, «contra tota evidència», 
que «en el fons Benjamin tenia, sense saber-ho, molt més en comú [amb Heidegger] que no pas amb les subtileses dialèctiques dels seus amics marxistes» (Löwy 2020: 15). Certament, hi hauria molt a dir sobre aquesta opinió interessada, que tant s'ha aprofitat, però aquest no és el lloc d'entrar-hi a fons. Puc afegir només que l'assaig que, als meus ulls, ha rebatut amb més rigor aquesta vinculació dubtosa amb Heidegger és el de Patricia Lavelle, Religion et histoire (Lavelle 2008: 237-244). Més tard, a Catalunya, el monogràfic «Walter Benjamin: les formes de la crítica», a cura de Paula Kuffer i Laura Llevadot, publicat en castellà el 2017 a la revista Enrahonar, del Departament de Filosofia de la UAB (disponible en xarxa), aborda també les preses de distància amb el pensament de Heidegger, i és Francisco Naishtat que hi dedica uns quants paràgrafs importants. En realitat, Naishtat segueix la mateixa línia de Lavelle, per bé que aquesta última hi aprofundeix molt més i també d'una manera més determinada: o sigui, que la diferència rau sobretot en la concepció del temps i de la història. Això no obstant, Naishtat s'equivoca quan assegura que el terme «Jetztzeit» és un neologisme encunyat per Benjamin (Naishtat 2017: 18), i el tradueix per «tiempo-ahora», que és com se sol traduir en castellà matusserament, atès que el terme existeix en alemany i significa simplement «actualitat» (Agamben 2006: 140), o, més literalment, «temps present». Per tant, em sembla inevitable veure-hi una rèplica al «Jetzt-Zeit» de què parla Heidegger a Ésser i temps. Com va assenyalar Ernst Bloch, el compost «Jetztzeit» no és nou; el que és nou és la significació que Benjamin li atribueix, segons la qual un esdeveniment passat, no retingut per la història, suara torna a tenir una plena actualitat (Bloch 1968: 16-23). D'aquesta manera, el contínuum es trenca per l'acció d'un present que s'esbadella, i això possibilita un moment inusitat de retrobada d'un passat amb ell mateix. És així que, de cop i volta, poden aparèixer reminiscències inesperades, que havien estat completament oblidades per la història. L'actualitat es mereix l'adjectiu de plena quan s'omple d'un temps que no comptava i que ara ja compta. Naishtat ho compara molt justament amb la traducció:

no se trata ni de reproducir o de revivir el mismo pasado, ni de identificarse empáticamente con el mismo, sino de «traducir» ese pasado en el presente, de modo que, en su transformación mediante dicha traducción, el pasado encuentra una presencia en el presente ofreciéndonos una experiencia que abre al presente y lo interrumpe, como interrumpe (y abre) la traducción a la lengua pròpia. (Naishtat 2017: 27)

Per Benjamin, les traduccions asseguren la «supervivència» d'una obra, perquè en són un desplegament, una prolongació en el temps i en una altra llengua. És així que permeten que l'obra s'actualitzi, que es renovi en una època futura. Com diu Naishtat, la traducció fa que l'obra irrompi de nou i desplaci la llengua amb la seva forma singular vinguda de fora i amb el seu contingut de veritat. Quan es tracta d'obres que ja s'han tornat significatives, pertanyen a un temps passat que troba una forma nova en un present. A més a més, amb cada retraducció, l'obra troba un nou acompliment — com si cada vegada fos cridada a remou- 
re les brases del foc intern que la manté viva. L'obra mateixa, pel fet de ser obra — i per tant de ser forma - , reclama aquesta expansió, aquest nou desenrotllament en una altra llengua. I així sobreviu en el temps una vegada i una altra. L'obra es realitza a si mateixa, doncs, per mitjà de la traducció. La vida de l'original dependrà de les traduccions que se'n vagin fent.

Tant la crítica en el vessant hermenèutic - que cerca desplegar el contingut de veritat d'una obra - com la traducció — que fa aparèixer l'obra en una altra llengua i en un altre temps- són conseqüències lògiques de l'obra en si, de resultes de la seva necessitat d'existir. Així doncs, la crítica pot entrar en l'àmbit de l'art, com també la traducció, per tal com l'una i l'altra en són la consumació. És el que pensava també Carles Riba.

En aquest mateix dossier d'Enrahonar hi ha un article de Patrick Vauday, «La traducción como crítica» (71-80), un títol que s'assembla a un de meu, «La traducció, un acte crític» (Pons 2020: 71-80), però que tenen poc a veure en el contingut. El text ha estat traduït del francès per la professora Ana Lanfranconi i la idea que s'hi pretén desenvolupar és que, amb la traducció, l'obra passa per una prova que li permet de sospesar la seva vitalitat i la seva consistència. Al cap i a la fi, Vauday recolza el títol del seu text en una sola frase: «la dimensión crítica de la traducción se encontraría ya desde el principio en la elección del texto a traduir.» La traducció és una forma de selecció de les obres: se'n tradueixen unes i no pas unes altres, o unes més que no pas unes altres. I n'hi ha que no es tradueixen mai. D'altres es tradueixen una vegada i una altra, gairebé com una necessitat, com ara la Bíblia, que és un cas paradigmàtic per a Benjamin. Tanmateix, Vauday no arriba a explicar ben bé de quina manera el treball del traductor s'expressa mitjançant una crítica del text que tradueix, tret que per crítica entengui l'esforç interpretatiu que per força implica tota traducció. Tampoc no diu enlloc que la tria de les obres que es tradueixen pot venir d'un poder que vol silenciar-ne unes a favor d'unes altres. Vauday sembla que per crítica entén sobretot el fet de triar uns mots i no pas uns altres, així com una forma en detriment d'una altra. Però més enllà d'això, poca cosa més. Tal vegada la traducció comentada d'un text difícil, seguint el model del Targum Onkelos de la Torà, podria anar en aquesta línia especulativa de què parla Vauday.

$$
* * *
$$

El pessic de ferment que ha provocat aquesta llarga exposició sobre la recepció de les Tesis benjaminianes a Catalunya —que d'altra banda no és exhaustivaha estat el fet poc usual que aquests textos hagin aparegut en tres traduccions els anys 2018, 2019 i 2020, respectivament, i que això, com ja he dit al començament, no hagi despertat l'interès de la crítica ni de les institucions o espais culturals, tot i haver-se esdevingut poc temps abans i durant el vuitantè aniversari de la mort del filòsof. Tampoc no hi ha hagut cap pensador(a), entre els (les) qui estan en voga $\mathrm{i}$ acostumen a reflexionar sobre les angoixes del present, que hagi cregut que aquests textos actualitzats valien la pena de ser rescatats arran de l'efemèride. Per la seva banda, el setembre del 2020 la Fundació Angelus Novus i l'associació 
Passatges de Cultura Contemporània van celebrar la Cinquena Escola d'Estiu Walter Benjamin sense la voluntat de fer dialogar o d'acarar aquestes tres traduccions disponibles, sinó que només es van centrar en la reedició del recull traduït per Pous amb la idea de «retre memòria a la lucidesa de Walter Benjamin i a la tasca pionera d'Antoni Pous» (Parcerisas 2020: 9), com si aquesta injunció de memòria no impliqués, per Benjamin, un desplegament del contingut de veritat d'una obra al llarg del temps, cosa que es du a terme per mitjà de les retraduccions: cadascuna desvetlla algun tret de l'obra que la fa particular. Tampoc van creure convenient presentar o comentar l'assaig en català de Michael Löwy, Avís d'incendi — guardonat amb el Premi Internacional Walter Benjamin, del qual diuen ser collaboradors-, preocupats com deuen estar en la cerca dels diners que donaran sentit a la seva existència. Llegir Benjamin avui mena a destapar també les omissions que se'n fan, mentre se l'eleva al panteó de les abstraccions hagiogràfiques, perquè tot això ofega l'alenada concreta de la revolta que els seus textos duen a dins.

És com a crític literari i com a pensador situat al marge que Benjamin va ser un combatent antifeixista i un adversari del capitalisme. Els seus textos són una reflexió de com es pot resistir al feixisme, de com se'l pot comprendre per combatre'1. Ell no el considerava una regressió ni una reculada cap a formes primitives, sinó que sostenia que podia donar-se en una societat culta i avançada. Per això veia amb mals ulls tota forma de submissió o claudicació cultural. Tant el nazisme com el feixisme van maldar per pervertir la modernitat tant com van poder, amb tota mena de falsificacions científiques i d'esoterismes, i van mobilitzar tots els instruments tècnics que van tenir a l'abast per dur a terme les seves ambicions totalitàries. En aquest sentit, no són un accident de la història; sempre ens podrem confrontar amb una nova forma de feixisme, que no serà mai idèntic al del segle Xx, per bé que presentarà unes constants que el faran identificable (l'odi a l'estranger i al diferent, el menyspreu pel migrant, la degradació de la democràcia per posar-la al servei d'un líder egòlatra i d'unes elits, el control de la població per mitjà de la por o l'entabanament, l'ús de l'aparell judicial i de la presó per eliminar els adversaris, la propagació de mentides com a arma política...). A més, Benjamin també va fer una crítica, pionera en la seva època, de la dominació de la natura mitjançant una explotació imparable dels recursos i de les matèries primeres que la Terra ofereix gratuïtament, com llegim a la Tesi XI. Per això sobta que L'Avenç i Crític tampoc no se n'hagin fet ressò (almenys ha estat així durant el 2019 i el 2020), i que ni tan sols no hagin ajudat a un debat sobre la vigència del seu pensament, o sobre la producció assagística de Michael Löwy. Tot i el Premi Internacional Walter Benjamin per la seva trajectòria, a Catalunya el llibre Avís d'incendi, que és la seva lectura de les Tesis, no ha tingut ni una trista ressenya. ${ }^{6}$

6. Mesos després d'haver lliurat aquest text als editors i quan l'assaig de Michael Löwy ja s'havia exhaurit a les llibreries (gràcies, lectors!), la secció catalana d'El País va publicar-ne finalment una ressenya de Joan Burdeus («Raspallar a contrapel», 15/3/2021). Com ja va passar, també a $E l$ País, amb la de Thomas l'Obscur, de Maurice Blanchot (Flâneur, 2019), aquesta ressenya no 
La celebració buida i el silenci interessat que agombolen, aquí i avui, l'obra de Benjamin són la prova fefaent que les fantasmagories de les illlusions burgeses són ben presents en els espais de l'esquerra contemporània, incapaç d'assumir una crítica dels propis canals i mediadors.

Quan la revista L'Espill (núm. 58, 2018) va publicar la traducció de Gustau Muñoz de l'opuscle Sobre el concepte d'història, havien passat trenta-quatre anys d'ençà que les traduccions d'Antoni Pous havien vist la llum pòstumament gràcies al volum Art i literatura (Eumo/Edipoies, 1984). Segons Muñoz, «l'eco d'aquests textos no ha deixat de ressonar des que Adorno i Horkheimer en feren una edició restringida el 1942. I potser ara, quan encarem un nou enfosquiment de la raó, ressona més que mai...». El fet que aquests textos ressonin avui més que mai vol dir que ens escometen i interpellen més que mai. Potser avui més que mai es tracta de saludar l'agressivitat positiva a què ens conviden Benjamin $\mathrm{i}$ Adorno (també Celan) des d'alguns dels seus textos, mitjançant el moment negatiu que necessiten tant la dialèctica com la poesia per poder ser.

A la seva tesi doctoral Antoni Pous, poeta i traductor (2001), Ramon Farrés ha estat del parer que fora millor no reeditar les traduccions dels textos de Benjamin que Pous havia fet: «probablement contenen massa errors perquè valgui la pena recuperar-les, ni tan sols retocant-les com ha fet recentment Pilar Estelrich amb el cèlebre assaig "La tasca del traductor"» (Farrés 2001: 471). Tanmateix, Pilar Parcerisas, presidenta de l'associació Angelus Novus de Portbou, s'expressa de manera contrària en el pròleg que acompanya la reedició del recull que ara surt amb el títol que se suposa que inicialment era el seu: Art i literatura de masses, tot i que no queda clar de quina «literatura de masses» es tracta en aquests textos, i és possible que això fes decantar els editors de Vic a escurçar-lo simplement en Art i literatura. Sobta també que el títol inicial que ha estat tan característic de la traducció de Pous per a l'assaig sobre «L'obra d'art en l'època de la seva reproduïbilitat [sic] tècnica» hagi estat retocat en aquesta reedició i ara digui 'reproductibilitat', però que se'n conservin les errades més greus de traducció, perquè dificulten entendre el que Benjamin volia dir, si no s'acaren amb les altres dues. Dos exemples cridaners del que acabo de dir són el concepte de der jüngste Tag, o sigui, «el judici final» —on diu: «welcher Tag eben der jüngste ist» (Tesi III), que Pous tradueix per «dia que és justament el novíssim», mentre que Gustau Muñoz ho diu així: «però aquest dia és justament el darrer», i Jiménez Buzzi: «un dia que no és altre que el del judici final»-, i també el concepte d'Ausnahmezustand (Tesi viII): «estat d'emergència» (Pous), «estat d'excepció» (Muñoz) i «estat d'excepció» (Jiménez Buzzi). De la mateixa manera, el concepte de Jetztzeit (Tesis XIV i XVIII) és donat de manera diversa: «suara-ara» (Pous), «temps d'ara» (Muñoz), «temps actual» (Jiménez Buzzi). La solució de Pous, vista des

comenta enlloc la textura de la traducció, perquè així no n'ha d'esmentar l'autor o autors. Es deuen pensar que alguns llibres —i més si són un repte, com ho és Blanchot-es tradueixen sols en català. Aquesta mala praxi no s'aplica tanmateix a tots els traductors; l'esborrament és pertinaç amb aquells que molestem amb el que escrivim quan no traduïm. No diré pas que amb Franco tinguéssim més sort perquè és fals, però aleshores la violència i la censura venien fonamentalment dels feixistes. Avui ja no és així. 
del mallorquí, que manté l'ús del suara ben viu, podria tenir una certa pertinència. De fet, sus ara vol dir 'a la vora de l'ara', i, per tant, s'utilitza per dir 'fa no res' (passat immediat) i 'd'aquí poc' (futur immediat), també per dir 'ara mateix' o 'just ara' (present immediat), però la fórmula de Pous no apareix a l'AlcoverMoll (només hi surt 'suara suara'), mentre que Jetztzeit sí que apareix als diccionaris alemanys, i en Benjamin significa l'actualització d'un passat en el present (com pot passar amb la moda, que converteix en últim crit una peça antiga). En la seva reformulació al francès, Benjamin escriu simplement «'présent'» (Benjamin 2019: 206; Tesi XIX). Algunes errades de la traducció de Pous són flagrants, com quan, a la Tesi I, tradueix: «Pot fer-se-les amb qualsevol que se serveixi de la teologia», mentre que les altres dues diuen respectivament: «Pot enfrontar-se a qualsevol i reeixir, si posa al seu servei la teologia» (Muñoz) i «Pot enfrontar-se a qualsevol com si res, sempre que tingui al seu servei la teologia» (Jiménez Buzzi). O quan a la Tesi Ix diu: «Té el seu esguard [Antlitz] girat al passat. On nosaltres veiem una cadena de dades, ell hi veu una sola catàstrofe que no para d'acumular ruïnes sobre ruïnes i que ell tragira [sic] amb el peu.» Mentre que les altres dues diuen: «Té el rostre girat cap al passat. On a nosaltres se'ns apareix una cadena d'esdeveniments, ell només hi veu una única catàstrofe, que amuntega sense parar ruïnes damunt ruïnes i les llança als seus peus» (Muñoz) i «Té la cara dirigida cap al passat. Allà on davant nostre apareix una cadena d'esdeveniments, ell hi veu una única catàstrofe que apila incessantment runes sobre runes $\mathrm{i}$ les hi llança davant dels peus» (Jiménez Buzzi). De fet, Antlitz és pròpiament 'faç' —més escaient per a un Àngel. D'altra banda, no sé per què aquesta nova reedició restitueix les cursives necessàries a la traducció de Pous, i reprodueix els errors de l'edició original. Un altre exemple el tenim a la Tesi xIV quan apareix 'el salt del tigre': «Aquest salt mateix sota l'esbarjós cel de la història és el salt dialèctic, tal com Marx va entendre la revolució» (Pous); «El mateix salt al camp lliure de la història és el salt dialèctic, la revolució tal com l'entenia Marx» (Muñoz); «El mateix salt, però a l'aire lliure de la història, és el salt dialèctic que Marx identificava amb la revolució» (Jiménez Buzzi). O fins i tot amb el final de la Tesi XVII: «El fruit nutritiu d'allò que és històricament comprès porta en si el temps com una mena de llavor preciosa però que es passa d'un sabor agradable» (Pous); «El fruit substanciós del que es comprèn històricament conté en el seu interior el temps com una llavor preciosa, però inaccessible al tast» (Muñoz) «El fruit nutritiu d'allò que s'ha comprès històricament conté en el seu interior el temps, com la llavor preciosa però mancada de gust» (Jiménez Buzzi). Podria allargar la llista d'exemples, però aquest no és el lloc de fer el que fa, a la seva manera, una tesi doctoral, amb el seu desgranar exemples i exemples. Potser puc acabar dient que, malauradament, durant la maquetació de la reedició de Pous un passatge que pertany a la pàgina 26 del llibre — i que de fet és de la Introducció de Pous-s'ha afegit per error al final de l'Annex B de la pàgina 171 (cosa que pot passar a tothom, certament). Com quan Jiménez Buzzi escriu «oportunitat messiànica» on hauria de dir «oportunitat revolucionària» (p. 65 i 131). També això — ai las! — són formes inevitables de manipulació — però aquestes, per sort, són innocents. 


\section{Referències bibliogràfiques}

Agamben, Giorgio (2006). «Umbral o tornada». A: El tiempo que resta. Comentario a la Carta a los Romanos. Traducció d'Antonio Piñero Sáenz. Madrid: Editorial Trotta, p. 135-142.

- (2011). Estado de excepción y genealogía del poder. Barcelona: Centre de Cultura Contemporània.

Benjamin, Walter (1983). L'obra d'art a l'època de la seva reproductibilitat tècnica. Tres estudis de sociologia de l'art. Edició i pròleg de J. F. Yvars. Traducció de Jaume Creus. Barcelona: Edicions 62.

- (1984). «Tesis sobre la filosofia de la història». A: Art i literatura. Tria de textos, traducció i introducció d'Antoni Pous. Pròleg de Manuel Carbonell. Vic: Eumo; Edipoies, p. 133-142.

- (2001). Assaigs de literatura contemporània. Selecció i pròleg d'Ignacio Echevarría. Traducció i notes de Pilar Estelrich. Barcelona: Columna.

— (2018). «Sobre el concepte d'història». Traducció de Gustau Muñoz. València: L'Espill, 58, p. 189-198.

- (2019). Sobre el concepte d'història. Traduccions de Marc Jiménez Buzzi i Arnau Pons. Barcelona: Flâneur.

— (2020). Art i literatura de masses. Pròleg de Pilar Parcerisas. Selecció de textos, traducció i introducció d'Antoni Pous. Portbou: Edicions Reremús; Fundació Angelus Novus per a l'estudi de les Arts, la Història i el Pensament.

BEnNÀssar, Sebastià (2020). «Walter Benjamin espera el centre on li retin memòria vuitanta anys després de la seva mort». VilaWeb (26 setembre) [en línia]. <https://www. vilaweb.cat/noticies/walter-benjamin-espera-el-centre-on-se-li-reti-memoria-vuitantaanys-despres-de-la-seva-mort-a-portbou/>.

Berdet, Marc (2014). Walter Benjamin: la passion dialectique. París: Armand Colin.

Berman, Antoine (2008). L'Âge de la traduction: "La tâche du traducteur» de Walter Benjamin, un commentaire. París: Presses Universitaires de Vincennes.

Bloch, Ernst (1968). «Über Walter Benjamin». A: Erinnerungen. Frankfurt: Suhrkamp Verlag, p. 16-23.

Bollack, Jean (2010). «Benjamin devant Kafla». A: Wismann, Heinz; Lavelle, Patricia (ed.). Walter Benjamin, le critique européen. Villeneuve d'Ascq: Presses Universitaires du Septentrion, p. 213-277.

BonadA, Lluís (2000). «Manipularan Walter Benjamin». Entrevista a Jordi Llovet. El Temps (26 setembre / 2 octubre), p. 52-55.

Butler, Judith (2014). «Walter Benjamin y la crítica de la violencia». A: ¿A quién le pertenece Kafka? Traducció de Cecilia Bettoni. Santiago de Xile: Palinodia, p. 63107.

Capella, Joan Ramon (1993). «El temps messiànic en l'últim Benjamin». A: Walter Benjamin i l'esperit de la modernitat. Edició de Jordi Llovet. Barcelona: Barcanova, p. 365-391.

Cassirer, Ernst (1947). El mito del Estado. Traducció d'Eduard Nicol. Mèxic D.F.: Fondo de Cultura Económica.

CARdín, Alberto (1993). «La història com a desesperació». A: Walter Benjamin i l'esperit de la modernitat. Edició de Jordi Llovet. Barcelona: Barcanova, p. 337-344.

Casals, Jaume (1993). «Sobre les tesis de filosofia de la història de Walter Benjamin». A: Walter Benjamin i l'esperit de la modernitat. Edició de Jordi Llovet. Barcelona: Barcanova, p. 329-335. 
De Launay, Marc (2010). «Messianisme et philologie du langage». A: Wismann, Heinz; Lavelle, Patricia (ed.). Walter Benjamin, le critique européen. Villeneuve d'Ascq: Presses Universitaires du Septentrion, p. 75-95.

De Murcia, Antonio (2018). «Cartesianismo y política del espíritu en Paul Valéry». Ingenuim. Revista Electrónica de Pensamiento Moderno y Metodología en Historia de las Ideas, 12, p. 1-22. $<$ https://doi.org/10.5209/INGE.62416>

FArrés, Ramon (2001). Antoni Pous, poeta i traductor. Tesi doctoral. Universitat Autònoma de Barcelona. [en línia] <https://www.tdx.cat/handle/10803/5254\#page=1>.

Fiтtкo, Lisa (2020). Le chemin Walter Benjamin. Souvenirs 1940-1941. Traducció de l'alemany de Léa Marcou. Pròleg d'Edwy Plenel. París: Éditions du Seuil.

Idel, Moshe (2013). «Abraham Aboulafia, Scholem et Benjamin». A: Benjamin - Cahiers de l'Herne. París: L'Herne, p. 326-334.

JARQUE, Vicente (1993). «Benjamin i el judaisme». A: Walter Benjamin i l'esperit de la modernitat. Edició de Jordi Llovet. Barcelona: Barcanova, p. 345-364.

KRISTAL, Efraín (2017). «Walter Benjamin: el mesianismo de la traducción». A: BenjaMIN, Walter. La tarea del traductor. Traducció de Fernando García Mendivil. Madrid: Sequitur, p. 30-39.

Lavelle, Patricia (2008). Religion et histoire. Sur le concept d'expérience chez Walter Benjamin. París: Éditions du Cerf.

Leslie, Esther (2000). «Crossing Borders: Walter Benjamin Conference in Barcelona. September 25-27 2000». [en línia] <http://www.arch.mcgill.ca/prof/sijpkes/D+Cwinter-2010/crossing.html\#overpowering $>$.

Löwy, Michael (1988). Rédemption et utopie. Le judaïsme libertaire en Europe centrale. París: PUF.

- (2018). «Walter Benjamin, marxiste-libertaire». Contretemps. Revue de critique communiste [en línia]. <https://www.contretemps.eu/walter-benjamin-marxiste-libertaire/ \#_ftnref5>.

- (2019). La révolution est le frein d'urgence. Essais sur Walter Benjamin. París: Éditions de l'éclat.

— (2020). Walter Benjamin. Avís d'incendi. Traducció d'Arnau Pons i David Cuscó. Barcelona: Flâneur.

Llovet, Jordi (1993). «Benjamin i París». A: Walter Benjamin i l'esperit de la modernitat. Edició de Jordi Llovet. Barcelona: Barcanova, p. 277-290.

- (2008). «Walter Benjamin a Catalunya». A: Carrers de frontera. Passatges de la cultura alemanya a la cultura catalana. Edició d'Arnau Pons i Simona Škrabec. Barcelona: Institut Ramon Llull, p. 368-371.

Lluró, Josep-Maria (2008). «L'estil Benjamin. Notes sobre la recepció de l'obra de Walter Benjamin a Catalunya». A: Carrers de frontera. Passatges de la cultura alemanya a la cultura catalana. Edició d'Arnau Pons i Simona Škrabec. Barcelona: Institut Ramon Llull, p. 364-367.

Meschonnic, Henri (2001). «Le messianisme, une utopie juive»; «L'allégorie chez Walter Benjamin». L'utopie du Juif. París: Desclée de Brouwer, p. 267-270, 281-324.

Mosès, Stéphane (1992). L'Ange de l'histoire. Rosenzweig, Benjamin, Scholem. París: Éditions du Seuil.

MunÁRriz, Ángel (2017). «Entrevista a Reyes Mate. "En la construcción nacional catalana hay una expresión del franquismo"». [en línia] <https://www.infolibre.es/noticias/ politica/2017/11/20/reyes_mate_construccion_nacional_catalana_hay_una_expresion_del_franquismo_72113_1012.html>. 
Naishtat, Francisco (2017). «El órganon invisible. La gramática teológica del tiempo benjaminiano». A: «Walter Benjamin, les formes de la crítica». A cura de Paula Kuffer i Laura Llevadot. Barcelona: Enrahonar, 58, p. 13-31. $<$ https://doi.org/10.5565/rev/enrahonar.1047>

Oyarzún, Pablo; Pérez López, Pablo; Rodríguez, Federico (ed.) (2017). Letal e incruenta. Walter Benjamin y la crítica de la violencia. Santiago de Xile: LOM Ediciones.

Parcerisas, Pilar (2020). «Pròleg». A: Benjamin, Walter. Art i literatura de masses. Portbou: Edicions Reremús; Fundació Angelus Novus per a l'Estudi de les Arts, la Història i el Pensament, p. 6-9.

Pinto, Raffaele (1993). «Aspectes de l'hermenèutica bíblica de Walter Benjamin». A: Walter Benjamin i l'esperit de la modernitat. Edició de Jordi Llovet. Barcelona: Barcanova, 57-64.

Plenel, Edwy (2020). «Le présent du passé». A: Lisa FitTKo. Le chemin Walter Benjamin. Souvenirs 1940-1941. París: Éditions du Seuil, p. 7-55.

Pons, Arnau (2020). La traducció, la vida. Pròleg de Joaquim Sala-Sanahuja. Catarroja: Afers.

Pous, Antoni (1984). «Introducció». A: Benjamin, Walter. Art i literatura. Vic: Eumo; Edipoies, p. 11-23.

Reyes Manuel, Lourdes (2017). Crítica del tiempo histórico. El espacio utópico como revolución kairológica. Universidad Autónoma de Madrid. (en línia) <https://repositorio.uam.es/bitstream/handle/10486/681318/reyes_manuel_lourdes.pdf?sequence= $1 \&$ is Allowed $=\mathrm{y}>$.

Rosàs Tosas, Mar (2016). Mesianismo en la filosofía contemporánea. De Benjamin a Derrida. Barcelona: Herder.

Tackels, Bruno (2012). Walter Benjamin. Una vida en los textos. Traducció de Josep Aguado i Inmaculada Miñana. València: Publicacions de la Universitat de València.

Taubes, Jacob (2005). Teologia política de Pau. Schmitt, Benjamin, Nietzsche, Freud. Traducció, adaptació i introducció de Jordi Galí i Herrera. Barcelona: Pòrtic, p. 179189.

VAlero, Vicente (2001). Experiencia y pobreza. Walter Benjamin en Ibiza (1932-1933). Barcelona: Península.

Valverde, José María (1993). «Abans de llegir Walter Benjamin». A: Walter Benjamin $i$ l'esperit de la modernitat. Edició de Jordi Llovet. Barcelona: Barcanova, p. 23-39.

Vauday, Patrick (2017). «La traducción como crítica». Traducció d'Anita Lanfranconi. A: «Walter Benjamin, les formes de la crítica». A cura de Paula Kuffer i Laura Llevadot. Barcelona: Enrahonar, 58, p. 71-80. $<$ https://doi.org/10.5565/rev/enrahonar.1041>

Wismann, Heinz (2013). «Le Littérateur». A: Benjamin - Cahier de l'Herne. París, p. $153-157$.

WitTe, Bernd (1992). Walter Benjamin. Traducció de Joan Leita. Barcelona: Edicions 62.

Wohlfarth, Irving (1999). Hombres del extranjero: Walter Benjamin y el Parnaso judeoalemán. Traducció d'Esther Cohen i Patricia Vilaseñor. Mèxic: Taurus. 
